\title{
Isolation, Phylogenetic Analysis of the Microbial Community Associated with the Red Sea Sponge Ircinia Echinata and Biological Evaluation of their Secondary Metabolites
}

\author{
Mohamed A Shreadah*1, Nihad M Abdel Monem² ${ }^{2}$ Galila A Yakout ${ }^{2}$ and Haiam M Aboul Ela ${ }^{1}$ \\ ${ }^{1}$ Marine biotechnology and natural products (MBNP) Laboratory, Egypt \\ ${ }^{2}$ Department of Biochemistry, Faculty of Science, Egypt
}

Received: 制: December 02, 2018; Published: ㄴㅔㅛ: December 17, 2018

*Corresponding author: Mohamed A Shreadah, Marine biotechnology and natural products (MBNP) Laboratory, Egypt

Abstract

The present study was undertaken to provide information about bioactive compounds of the microbial community associated with Ircinia echinata marine sponge collected from the Red Sea. This work investigated the antioxidant and cytotoxicity properties of the tested extracted crude extract. Sponge was taxonomically identified as Ircinia echinata. Moreover, taxonomic and phylogenetic analyses of the bacteria on the basis of $16 \mathrm{~S}$ rRNA gene sequences showed that dominant phylum was proteobacteria. The results of HPLC analysis revealed that the bacterial crude extracts exhibited highly significant quantities of total phenolic contents in crude extracts of the two tested bacterial isolates. The highest level of total phenolic contents was measured in the extract was shown in extracts HA-MS-41 (3.238 $\pm 0.03 \mathrm{mg}$ gallic equivalent/ml). Whereas, the lowest value was shown in extract HA-MS-118 (2.946 $\pm 0.10 \mathrm{mg}$ gallic equivalent $/ \mathrm{ml})$.

The results of the current study cleared out that extract HA-MS-41[JX484800] contained gallic and tannic acids $(1.084$ and $1.413 \mathrm{mg} / \mathrm{ml})$, whereas extract HA-MS-118 [JX484801] contained gallic $(1.005 \mathrm{mg} / \mathrm{ml})$ but didn't contain tannic acid. The highest level of total flavonoid content was measured in the extract HA-MS-41 extract $(5 \pm 0.23 \mathrm{mg}$ catechin equivalent / $\mathrm{ml})$. Whereas, much lower value was shown in the HA-MS-118 extract $(2.5 \pm 0.26 \mathrm{mg}$ catechin equivalent $/ \mathrm{ml})$. Carotenoid compounds significantly varied among the two bacterial extracts; the highest total carotenoid concentration was observed in the extract HA-MS- $41(1.165 \mu \mathrm{g} / \mathrm{ml})$. Whereas, lower valuesobserved in the extract HA-MS-118 $(0.185 \mu \mathrm{g} / \mathrm{ml})$. In the meantime, GC/MS profiling for the ethyl acetate extract of the studied sponge-associated bacteria revealed the presence of various phytochemical compounds having different biological activities. Results of FTIR spectroscopic studies have revealed the presence of various chemical constituents in ethyl acetate extract of the HA-MS-41 and HA-MS-118 bacterial isolates.

The results of the elemental analysis indicated that the bacterial extracts contained major elements like $\mathrm{Na}, \mathrm{Mg}, \mathrm{Al}, \mathrm{Si}, \mathrm{S}, \mathrm{K}, \mathrm{Ca}, \mathrm{P}$ and $\mathrm{Cl}$, besides the major elemental constituents in all living organisms; $\mathrm{C}, \mathrm{N}$ and $\mathrm{O}$. The results showed considerable concentrations of many halides (Fe, $\mathrm{Cu}, \mathrm{Zn}$ and Br). DPPH scavenging activity in terms of IC50 values was shown to be high in case of the extract HA-MS-41 (1.045 mg/ml) and in case of the extract HA-MS-118 $(1.450 \mathrm{mg} / \mathrm{ml})$. IC50 values of the antioxidant activity of bacterial extracts using NO assay for the tested two extracts were 5.98 and $6.222 \%$. Moreover, potent antioxidant activity using ABTS+ assay with percentages inhibition of IC50 = 3.404 and $1.64 \mathrm{mg} / \mathrm{ml}$ for HA-MS-41and HA-MS-118, respectively. In the present study highly significant total antioxidant capacity values was also obtained by using phosphomolybdenum assay in the bacterial extract suggesting the presence of effective antioxidants in the bacterial extract.

The high potency of these isolates is mainly attributed to the presence of various classes of potentially active secondary metabolites detected in them. Indeed phenols, tannins, and alkaloids identified in the tested extracts have been reported to possess antioxidant and anticancer activities. The relative wide range of these biologically properties may results from the individual or from the combined modes of action of compounds belonging to the identified groups of constituents. The cytotoxicity screening studies revealed that the maximum cell growth inhibitory effects of bacterial crude extracts against the tested cancer cell lines; HepG2; HCT and MCF-7 were found to be 22.7, 14.6, and $12.2 \mu \mathrm{g} / \mathrm{ml}$, respectively for HA-MS-41, and 36.5, 23.6, and $11.9 \mathrm{\mu g} / \mathrm{ml}$, respectively for HA-MS-118. These results were confirmed by a protein kinase inhibition specialized screening revealing an inhibition activity of $87.93 \pm 0.51$ and $94.24 \pm 1.15 \%$ for HA-Ms-41and HA-Ms- 118 .

Keywords: Sponge Associated Bacteria; Phylogenetic Analysis; Bioactive Metabolites

Abbreviations: NIWA: National Institute of Water and Atmospheric Research; PCR: Polymerase Chain Reaction; SEM: Electron Microscope; EDX: X-ray Spectrophotometer, DPPH: Diphenyl- $\alpha$-picrylhydrazyl, RP: Reversed-Phase, BHT: Butylated Hydroxytoluene; BHA: Butylated Hydroxyanisole; TAO: Total Antioxidant Capacity; HepG2: Hepatocellular Carcinoma 


\section{Introduction}

The marine life has an immense potential as a source of novel bioactive compounds which has been barely investigated. Natural products from marine sponges exhibit unique structural features which are of paramount interest for the scientists for the identification of new lead structures for potential drugs. Sponges (phylum Porifera) are known to be extremely rich sources of bioactive compounds, mainly of secondary metabolites of pharmaceutical and medical relevance. The development of secondary metabolites from the Red Sea sponges offer a potential for producing novel drugs and prototypes and has been a subject of intense research due to their immense bioactive nature [1-9]. They are also well known to be hosts for a large community of microorganisms $[1,10]$. Associations between higher organisms and microorganisms often occur as mutualistic or symbiotic relationships, by providing benefits for both in terms of protection and nutritional requirements [11-13]. These microorganisms can make up $35-60 \%$ of the total sponge mass and are responsible for the production of numerous bioactive compounds with unique, complex and different structure compared with terrestrial microorganisms $[4,10]$. Production of secondary metabolite is influenced by the environment. Inhibitory interactions among sponge-associated bacteria that occur within the sponge surface are of great interest to search for secondary metabolite-producing bacteria. In the meantime, they are the richest source of microbial community. So far, the bacterial community associated with sponge in the Red Sea remains unexplored. They produce diverse and unique bioactive secondary metabolites. This is an adaptation strategy to thrive in the extreme environmental conditions of the sea and as a defense strategy to escape from predators by the marine invertebrates especially soft bodied animals like sponges [14].

Since the marine environment is composed of a myriad of ecologically distinct habitats, it is not surprising that bacteria adapted to life in the marine environment are both diverse, phylogenetically distinct, and maintain survival adaptations that differ from bacteria that occur on land. These bacteria are widely reported to be highly potential as the producer of antimicrobial bioactive compound [11,12,15]. Numerous types of infectious diseases caused by pathogenic bacteria or yeast are one of basic problems in biomedical field that need to be seriously controlled. Therefore, the isolation of the microorganisms responsible for the origin of the bioactive products of interest will enable large-scale production of marine pharmaceuticals by means of fermentation technology. Despite having more than $2250 \mathrm{~km}$ coastline along the Red Sea, Egyptian studies concerning marine natural products related to drugs discovery are still very scarce. So far only a few classes of Egyptian marine organisms have been investigated for their chemical and pharmacological properties. Therefore it is believed that the identification of Egyptian organisms with significant biotechnological potential is an important tool for the discovery of new drugs. The main objective of the present study is to isolate and carry out a phylogenetic analysis of the microbial community associated with the Red Sea Sponge Ircinia echinata in in order to explore their different secondary metabolites of biological activity and to characterize their potential as antioxidant and anticancer.

\section{Materials and Methods}

\section{Sponge Collection}

Sponge samples were collected in May, 2010 from the Red Sea by SCUBA diving in (Figure 1). The physical, chemical, and biological characteristics of the Red Sea marine environment have been very recently extensively investigated [1-9; 16-31]. Samples were cut from the sponge with a dive knife while wearing latex gloves and individual pieces were transferred to separate plastic sample collection bags, brought to the surface, maintained at ambient seawater temperature and transported to the laboratory in the same day of collection. Sponge specimens were rinsed in sterile seawater, cut into pieces of ca. $1 \mathrm{~cm}^{3}$, and then thoroughly homogenized in a sterile mortar with 10 volumes of sterile seawater. The supernatant was diluted in ten-fold series (10-1, 10-2, 10-3) and subsequently plated out on agar plates.

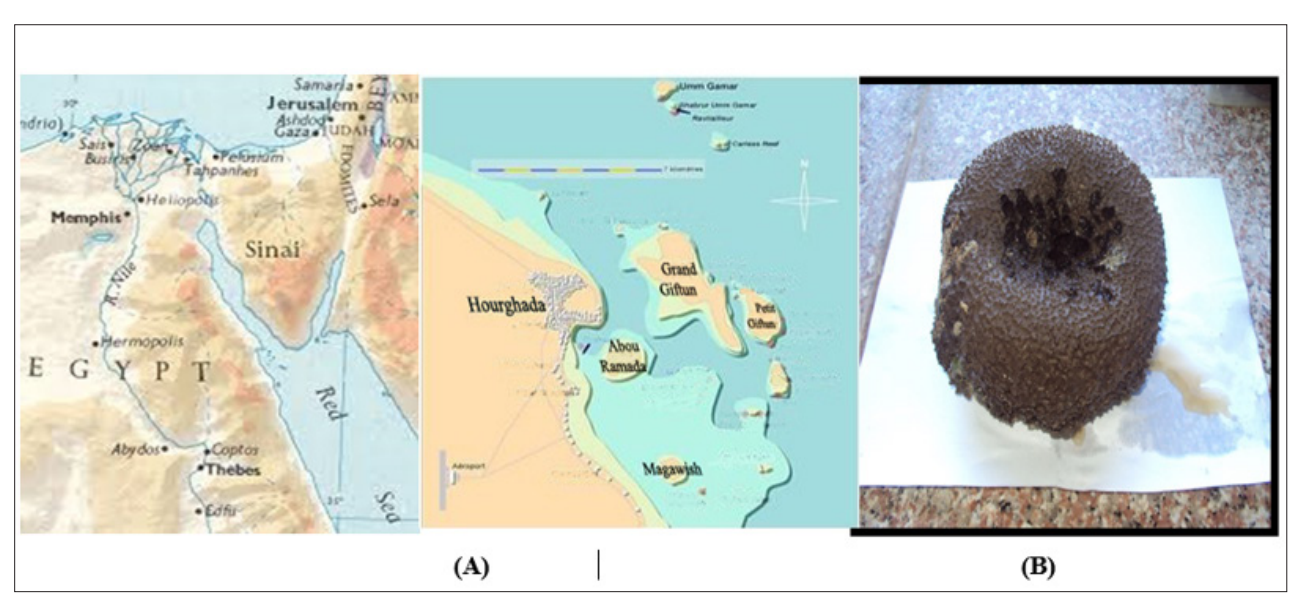

Figure 1: Map of Egypt showing (A) the sampling sites at Hurghada and (B) the Red Sea Ircinia echinata Sponge. 
Taxonomic Identification and Processing of the Sponge Sample: Sponge was taxonomically identified by Prof. Michele Kelly at National Institute of Water and Atmospheric Research (NIWA) Ltd., Auckland, New Zealand as Ircinia echinata (Order: Dictyoceratida; Famly: Irciniidae). A voucher specimen has been deposited at the Auckland War Memorial Museum. A voucher specimen of the sponge sample has been deposited in the NIWA Museum, under registration number NIWAKD 6672. Sponge was transferred to plastic bags containing sea-water and transported to the laboratory. Sponge specimen was rinsed in sterile seawater. Fresh specimen of each sponge was used for isolation of the spongeassociated bacteria. A section of sponge was immediately used to culture the sponge associated bacteria. Another section of sponge was immediately frozen on dry ice and stored at $-80^{\circ} \mathrm{C}$. The sponge tissue was then freeze-dried prior to DNA extraction.

Isolation of Sponge Associated Bacteria: Two growth media were prepared to isolate a wide range of the sponge associated bacteria; Marine Agar [32], and ISP medium 2 [33] served as general rich media to grow many heterotrophic marine bacteria. All media were supplemented with $0.2 \mu \mathrm{m}$ pore size filtered cycloheximide $(100 \mu \mathrm{g} / \mathrm{mL})$, nystatin $(25 \mu \mathrm{g} / \mathrm{mL})$ and nalidixic acid $(25 \mu \mathrm{g} / \mathrm{mL})$. Cycloheximide and nystatin inhibit fungal growth, while nalidixic acid inhibits many fast-growing Gram-negative bacteria [34]. All media contained Difco Bacto agar (18 g/L) and were prepared in $1 \mathrm{~L}$ artificial sea water $\left(\mathrm{NaCl} 234.7 \mathrm{~g}, \mathrm{MgCl}_{2} \cdot 6 \mathrm{H} 2 \mathrm{O} 106.4 \mathrm{~g}, \mathrm{Na}_{2} \mathrm{SO} 4\right.$ $39.2 \mathrm{~g}, \mathrm{CaCl}_{2} 11.0 \mathrm{~g}, \mathrm{NaHCO}_{3} 1.92 \mathrm{~g}, \mathrm{KCl} 6.64 \mathrm{~g}, \mathrm{KBr} 0.96 \mathrm{~g}, \mathrm{H}_{3} \mathrm{BO}_{3}$ $0.26 \mathrm{~g}, \mathrm{SrCl}_{2} 0.24 \mathrm{~g}, \mathrm{NaF} 0.03 \mathrm{~g}$ and $\mathrm{ddH}_{2} \mathrm{O}$ to $10.0 \mathrm{~L}$ ) [35]. The inoculated plates were incu-bated at $28^{\circ} \mathrm{C}$ for $5-10$ days. Distinct colony morpho-Types were picked and re-streaked until visually free of contaminants. Isolates were inoculated into liquid media ISP medium 2. The isolates were maintained on plates for short-term storage and long-term strain collections were set up in medium supplemented with $30 \%$ glycerol at $-80^{\circ} \mathrm{C}$ [36].

Extract Preparation and Cytotoxic Activity Screening: Bacterial isolates were cultured in $500 \mathrm{~mL}$ Erlenmeyer flasks containing $200 \mathrm{~mL}$ of ISP2 medium. The liquid cultures were grown for 7 - 14 days depending on their growth rate at $30^{\circ} \mathrm{C}$ while shaking at $150 \mathrm{rpm}$. Crude extracts were prepared from whole cultures; containing cells and broths by ethyl acetate equal volume/three times, evaporated, lyophilized and dissolved in 1:1 v/v DMSO/H2O and kept at $4^{\circ} \mathrm{C}$ until use for cytotoxic assay. The MTT (3-(4,5Dimethylthiazol-2-yl)-2,5-diphenyl tetrazolium bromide) assay which Measuring the mitochondrial re-ductase enzyme activity of viable cells that Could reduce MTT to formazan, giving a purple color, was used for screening the cytotoxicity of the bacterial extracts [37]. The cytotoxic activity of the microbial crude extracts was determined against three established cancer cell lines; MCF-7, HepG2 and HCT cells. Based on the values of the IC50, the most potent four bacterial extracts which exhibited the lowest IC50 were chosen for further study of their phylogenetic analysis and identification.

\section{Molecular Identification of the Bacterial Isolates}

Genomic DNA Extraction: Bacterial DNA was extracted using QIAgen DNAesy Blood and Tissue Kit (Cat. \# 69506), following manufacturer's guidelines
Polymerase Chain Reaction (PCR) Amplification of 16S rRNA: Following extraction of genomic DNA, polymerase chain reaction (PCR) was carried out in order to amplify the 16S rRNA gene, the primers used to amplify the 16S rRNA gene were two universal bacterial primers: Forward primer $27 \mathrm{f}$ (5'-AGAGTTTGATCCTGGCTCAG-3') and reverse primer 1492r (5'-GTTACCTTGTTACGACTT-3') designed to target the conserved regions of the 16S rRNA gene [38].

DNA Sequencing and Constructing the Phylogenetic tree: The isolated bacteria were first identified to the species level by PCR amplification of the 16S rRNA gene, BLAST analysis, and comparison with sequences in the GenBank nucleotide database. Specifically, the 16S rRNA gene from the strain was amplified using universal primers 27f (5'-AGAGTTTGATCCTGGCTCAG-3') and 1492r (5'-GGTTACCTTGTTACGACTT-3'). The PCR conditions used were the same as those described previously [39]. The PCR products were purified and sequenced by the GATC-Biotech. Company (Tübingen, Germany). The sequences were compared with known sequences in the GenBank nucleotide database and the species level was identified as the nearest phylogenetic neighbor with $98 \%-100 \%$ similarity [40]. Sequence alignment and phylogenetic analysis were performed using the Mega-5 software package [41]. Tree construction was conducted using neighbor joining algorithm (Jukes-Cantor correction) with bootstrap values based on 1000 replications. The 16S rRNA gene sequences the isolates were deposited in GenBank under the accession Numbers indicated in brackets: HA-41 [JQ768238] and HAMS- 118 [JQ768240].

\section{Chemical Investigations of the Bacterial Isolates}

Analytical HPLC analysis: $20 \mu \mathrm{l}$ sample extract was analyzed with a Exclipse XDB C18 (5 $\mu \mathrm{m}, 4.6 * 150 \mathrm{~mm}$ ) column using a mobile phase consisting $1 \%(\mathrm{v} / \mathrm{v})$ formic acid in aqueous solution: acetonitrile: 2-propanol (70:22:8), $\mathrm{pH} 2.5$; flow rate: $0.75 \mathrm{ml} / \mathrm{min}$, temperature: $30 \mathrm{oC}$, UV detection at $320 \mathrm{~nm}$; Agilent technologies 1200 series. Phenolic compound concentrations were calculated from the standard curves of the supplied phenolic standards exist in the data library

Gas Chromatography- Mass Spectrophotometeric (GC-MS) analysis: Analysis was conducted using Gas Chromatography-Mass Spectrophotmeter; GC-MS (Trace DSQII MS). MS conditions were as follows: Detector mass spectrometer voltage $70 \mathrm{eV}$ and its source temperature was $300^{\circ} \mathrm{C}$. The injector temperature was $240^{\circ} \mathrm{C}$ and the split less mode $0.5 \mu \mathrm{L}$ injection. The HP 55\% dimethyl-95\% dimethyl tertiary-butyl non-polar column was performed with length $30 \mathrm{~cm} \times 0.25 \mathrm{~mm}$, coating thickness film $0.25 \mu \mathrm{m}$. The oven was adjusted at $80^{\circ} \mathrm{C}$ for $1 \mathrm{~min}$ and initial time $1.5 \mathrm{~min}$ with $40^{\circ} \mathrm{C}$ which ended by a final temperature of $300^{\circ} \mathrm{C}$ and $4 \mathrm{~min}$ hold time where the total run time was $15 \mathrm{~min}$. The compounds were identified by comparison with the standards, and also matched with the in-built libraries. The components were identified by comparing their retention times with those of authentic samples, as well as by comparing their mass spectra with those of Wiley 275 Library [42]. Quantitative data were obtained by the peak normalization technique using integrated FID response.

Infrared Analysis (FT-IR): Using Perkin-ELMER1430 infrared spectrophotometer, the molecular structure of the extracts 
was partial identified. Separated spots of each compound were collected by scratching and dissolved in $1 \mathrm{ml}$ ethyl acetate and lyophilized then small discs made from the mixture of about $1 \mathrm{mg}$ of the lyophilized material and 300mg of pure and dry $\mathrm{KBr}$ were subjected to IR-spectroscope. The measurement were carried out at infrared spectra between 400-4000 $\mathrm{nm}$.

Elemental Analysis: The bacterial extracts were subjected to the elemental analysis using Scanning Electron Microscope (SEM) with an energy dispersive x-ray spectrophotometer (EDX). This was carried out at the Regional Center for Mycology and Biotechnology, Al-Azhar University, Egypt.

Determination of Total Phenolic Contents: Total phenolic compounds in the fungal extracts were determined by the method of [43]. One hundred microliters Folin-Ciocalteau reagent (50\%, v/v) in distilled water and $2 \mathrm{ml}$ sodium carbonate $(2 \%, \mathrm{v} / \mathrm{v})$ in distilled water were added and mixed well with $100 \mu \mathrm{l}$ of fungal extract. After $2 \mathrm{~h}$ incubation at RT, the absorbance of the resulting blue color solution was measured at $750 \mathrm{~nm}$. Different concentrations $(0-0.9 \mathrm{mg} / \mathrm{ml})$ of standard gallic acid were used and processed similarly as sample. The concentration of total phenolic in bacterial extracts was determined as mg gallic acid equivalent in $1 \mathrm{ml}$ of the extract using the standard curve of the gallic acid.

Determination of Total Flavonoid Contents: Total flavonoid content was determined by a colorimetric method of [44]. A $0.25 \mathrm{ml}$ of fungal extract or (+)-catechin standard solution was mixed with $1.25 \mathrm{ml}$ of distilled water, followed by the addition of $0.75 \mathrm{ml}$ of $5 \%$ sodium nitrite solution. After $6 \mathrm{~min}, 0.15 \mathrm{ml}$ of $10 \%$ aluminum chloride solution was added and the mixture was made up to $2.5 \mathrm{ml}$ with distilled water and well mixed. The absorbance was measured immediately at $510 \mathrm{~nm}$ using a spectrophotometer. The results were expressed as mean $\mathrm{ml}$ of $(+)$-catechin equivalents.

\section{a) Bioactivity screening of the bacterial extracts \\ b) Anticancer activity screening \\ c) Cytotoxicity against cancer cell lines \\ d) Cytotoxicity evaluation using viability assay}

For cytotoxicity assay, the cells were seeded in 96-well plate at a cell concentration of $1 \times 104$ cells per well in $100 \mu \mathrm{l}$ of growth medium. All experiments were carried out in the triplicate. The cell cytotoxic effect of each tested compound was calculated $[45,46]$.

Protein kinase Inhibitory Effect: Protein kinase inhibitory effect of the tested bacterial extract was determined by Universal Tyrosine Kinase Kit; Takara (CAT \# MK410) [http://www.takara. co.kr/file/manual/pdf/MK410_e.pdf] following the manufacturer's instructions with some modifications.

\section{In vitro Antioxidant Capacity Screening}

\section{Diphenyl- $\alpha$-picrylhydrazyl (DPPH) radical scavenging assay}

DPPH radical scavenging assay (Figure 24) of the extracts was performed by using modified previously established methodology by Blois [47], and Amarowicz et al. [48]. Assays were performed in flat bottom polystyrene 96 well microtiter plates. To $100 \mu \mathrm{L}$ of each sample $(1-6 \mathrm{mg} / \mathrm{ml})$ in EtOH $25 \mu \mathrm{L}$ DPPH $(1 \mathrm{mM})$ in ethanol was added. The resultant mixture was briefly shaken and maintained at room temperature, in the dark for $30 \mathrm{~min}$. At the end of this period the absorbance (A) of the mixture was measured at $490 \mathrm{~nm}$, using Microplate reader spectrophotometer. Scavenging ratio of DPPH assay was calculated as follows:

$$
\% \text { scavenging }=[(\text { A control }- \text { A sample }] / \text { A control })] \times 100
$$

\section{Nitric Oxide Scavenging Activity}

The extent of inhibition of nitric oxide radical generation in vitro was followed as per the method reported by Green et al. [49].

\section{ABTS+ Scavenging Effects}

The antioxidant effect of the leaf extracts was studied using ABTS (2,2'-azino-bis3-ethylbenzthiazoline-6-sulphonic acid) radical cation decolourisation assay according to the method of Shirwaikar et al. [50].

Inhibition $(\%)=($ Control - test $) /$ Control $\times 100$

All Measurements were expressed as Trolox equivalents. Standard regression line for Trolox was used to calculate TEAC values.

\section{Phosphomolybdenum Assay}

This assay is a spectroscopic method for the quantitative determination of antioxidant capacity, through the formation of phosphomolybdenum complex.

\section{Statistical Analysis}

All experiments were conducted at least with 3 replicates and the results were expressed as mean of 3 independent experiments + SEM calculated using Graph pad prism version 6.0.

\section{Results and Discussion}

\section{Recovery of Bacterial Isolates from the Culture Media}

Based on the morphological characteristics and uniqueness, two isolates from sponge Hyrtios erectus. The bacterial isolates were given codes prior to identification (Table 1).

\section{Molecular Identification of the Bacterial Isolate}

DNA Base Composition and Sequencing of the $16 \mathrm{~S}$ Ribosomal DNA (rDNA): The 16S rRNA genes were amplified by using general bacterial primers. The forward primer $(27 \mathrm{f}$ 5'-CCAGAGTTTGATCCTGGCTCAG-3') and reverse primer (1492 r 5'-TAC CTT GTT ACG ACT T-3') were used for amplification of $16 \mathrm{~S}$ rRNA genes the studied bacterial isolate. The amplified 16S rRNA gene was $1.5 \mathrm{~kb}$.

Sequence Alignments and Phylogenetic Inference: The bacterial isolate was identified using a molecular approach. The results showed that the $16 \mathrm{~S}$ rRNA genes belonged mainly to the phyla proteobacteria. The sequence were deposited in the GenBank database. Accession numbers [JX484800] corresponded to the 
strain HA-MS-41 and [JX484801] corresponded to the strain HAMS-118 (Table 1). For the Ircinia echinata sponge sample, bacterial PCR product was sequenced and phylogeneticaly analyzed (Figures 2 \& 3). The present study revealed that the identified bacterial species was Proteobacteria (especially Gamma- Proteobacteria). The phylum Proteobacteria are always found in different sponges from the same or different geographic location. Proteobacteria have been suggested to have varied effects on sponge hosts such as nitrogen fixation and manipulating host reproduction. It has been reported that Proteobacteria produce low molecularweight biological active compounds with bioactive properties. Proteobacteria were also found to produce enzymes at high levels for degrading protein and polysaccharides (Thomas et al.). Based on our results, phylum Proteobacteria are the predominant bacteria in the Ircinia echinata Red Sea sponge. So far different groups of antimicrobial bacteria including $\alpha, \beta$ and $\gamma$ proteobacteria have been isolated from different sponges from geographically different regions [51].

Table 1: Morphological characteristics and code numbers of the isolated bacteria from the studied sponge samples.

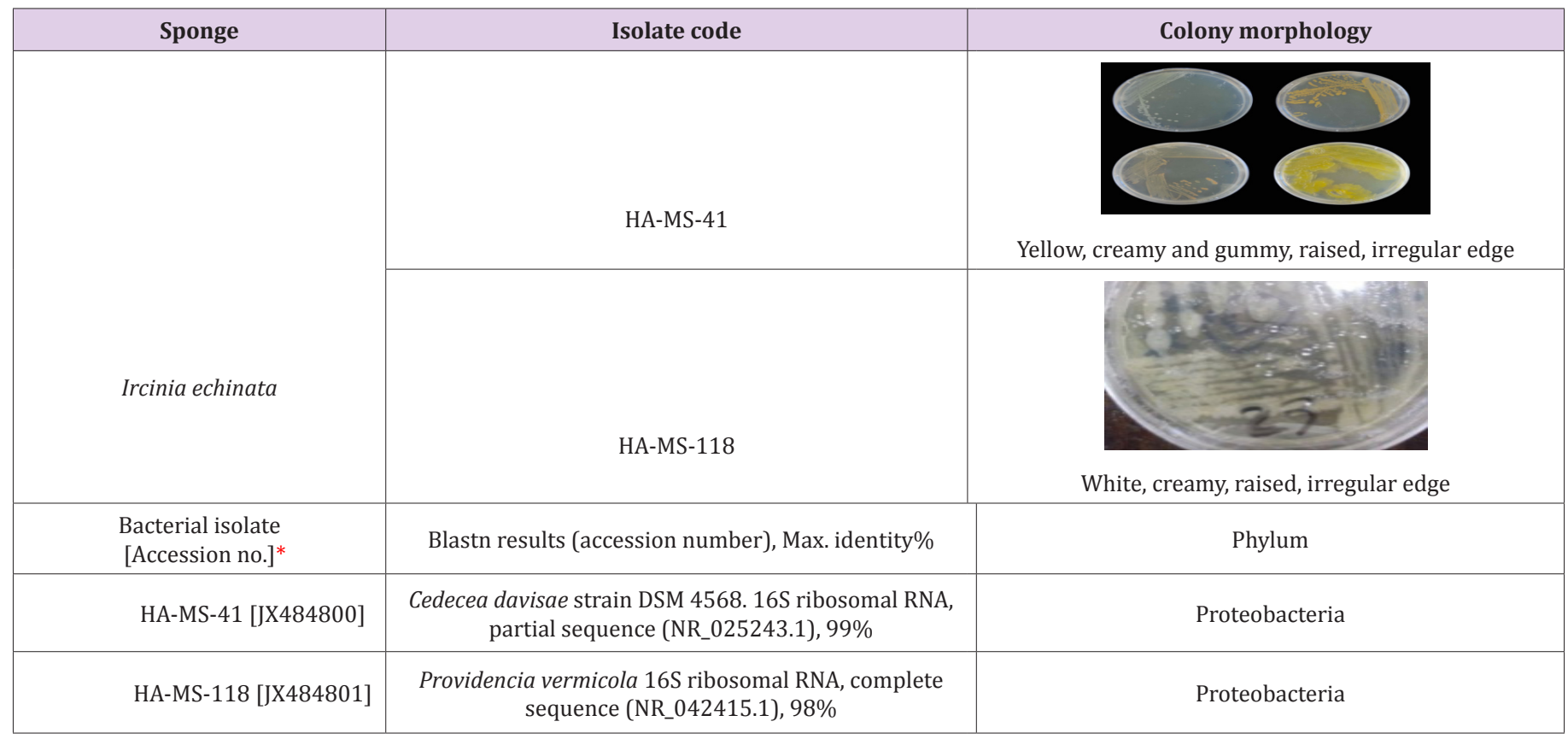

*Accession numbers obtained for the bacterial isolates upon submission in the Gen Bank.

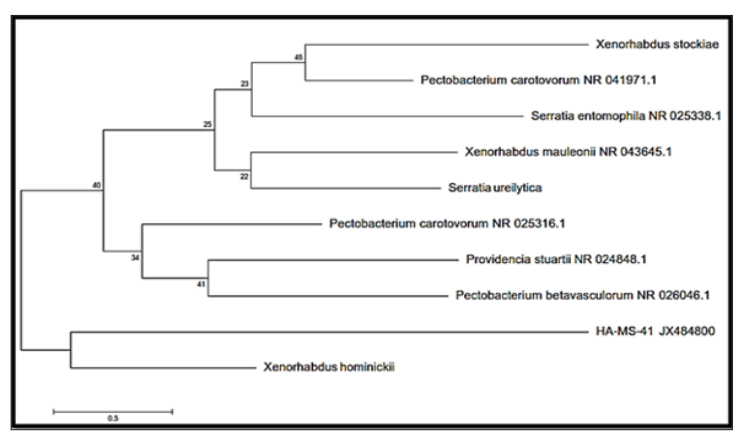

Figure 2: Molecular Phylogenetic anaylsis of the bacterial isolate HA-MS-41 by Maximum Likelihood method. The scale bar indicates 0.5 substitutions per nucleotide position.

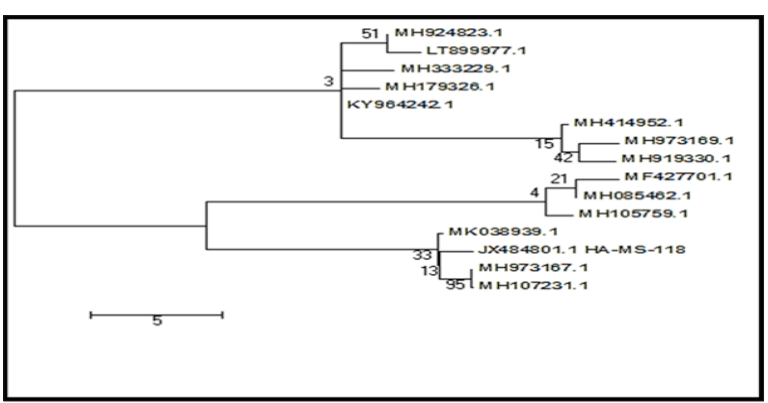

Figure 3: Molecular Phylogenetic anaylsis of the bacterial isolate HA-MS-118 by Maximum Likelihood method. The scale bar indicates 5 substitutions per nucleotide position. 
Chemical Investigation of the Bacterial Extract: Ethyl acetate extract of the bacterial isolate was subjected to chemical profiling and characterization using HPLC, GC/MS, FT-IR and elemental analysis techniques.

Analytical HPLC Analysis: The results obtained from HPLC analysis against a wide range of phytochemical standards revealed that there were considerable amounts of well-established bioactive compounds such as phenolic compounds, terpenoids and carotenoid compounds.

\section{Phenolic Compounds}

The obtained results from the analytical determination of reversed-phase (RP) HPLC against wide range of phytochemical standards revealed that the bacterial exhibited variable patterns of phenolics compounds (Table 2). Chlorogenic acid, 3,5-Dicaffeoyl quinic acid, and 4,5-Dicaffeoyl quinic acid were the main phenolic compounds present in the HA-MS-41 [JX484800] crude extract, whereas Chlorogenic acid and 3,5-Dicaffeoyl quinic acid were present in the HA-MS-118 [JX484801] crude extract. Two of the most powerful phenolic compounds are gallic and tannic acids were also determined by the HPLC analysis for the tested bacterial extracts (Figure 4). The results of the current study cleared out that extract HA-MS-41[JX484800] contained gallic and tannic acids, whereas extract HA-MS-118 [JX484801] contained gallic acid but didn't contain tannic acid (Table 3). Gallic acid is commonly used in the pharmaceutical industry. It seems to have anti-fungal, antiviral and antioxidant properties as it helps to protect human cells against oxidative damage. It was found also to show cytotoxicity against cancer cells, without harming healthy cells. Gallic acid is also used to treat albuminuria and diabetes [52].

Table 2: Phenolic compounds concentrations of the tested bacterial extracts.

\begin{tabular}{|c|c|c|c|c|}
\hline \multirow{2}{*}{ Extract } & \multicolumn{4}{|c|}{ Phenolic contents $(\boldsymbol{\mu g} / \mathbf{m l})$} \\
\cline { 2 - 5 } & Chlorogenic acid & Caffeic acid & 4,5-Dicaffeoyl quinic acid & Total \\
\hline HA-MS-41 [JX484800] & 1.865 & 1.165 & 1.961 & 4.991 \\
\hline HA-MS-118 [JX484801] & 2.396 & 5.642 & 2.331 & 10.369 \\
\hline
\end{tabular}

N.D.: not detected. All analyses were mean of triplicate measurements.

Table 3: Concentrations of Gallic and Tannic acids in the tested bacterial extracts.

\begin{tabular}{|c|c|c|}
\hline Extract & Concentration of Gallic acid (mg/ml) & Concentration of Tannic acid (mg/ml) \\
\hline HA-MS-41 [JX484800] & 1.084 & 1.005 \\
\hline HA-MS-118 [JX484801] & 1.413 & N.D. \\
\hline
\end{tabular}

*ND: not detected. All analyses were mean of triplicate measurements.

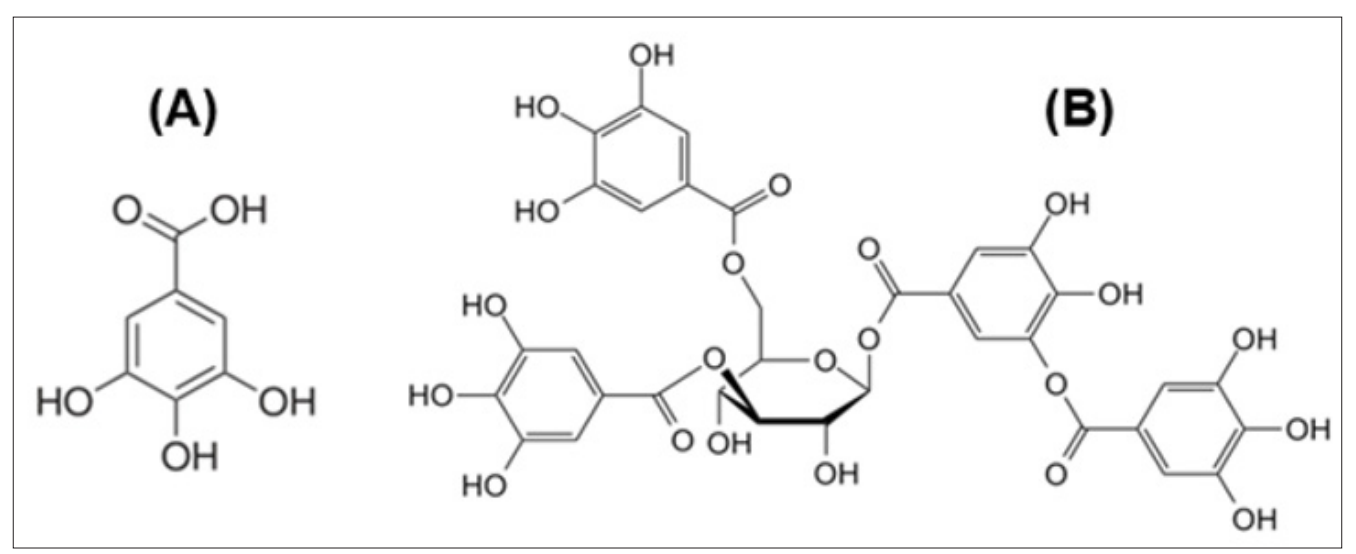

Figure 4: Structure of Gallic acid (A) and Tannic acid (B).

Tannic acid, on the other hand, is another phenolic compound that has been found in one of the two extracts. It is a specific commercial form of tannin, a type of polyphenol. Tannins are natural products have large amounts of phenolic rings in the structure and classified into two groups: hydrolyzable and condensed. Condensed tannins contain flavonoids units with several degrees of condensation. Hydrolyzable tannins are considered a mixture of simple phenols with ester linkages in its structure. There are many factors such as alkaline compounds, mineral acids, and enzymes that have the ability to hydrolyze tannins [53]. Tannic acid was used as a treatment for many toxic substances. Moreover, it has been stated that the broad spectrum biological activity of some sponges are mainly due to the presence of terpenes, alkaloids and tannins detected in the bioactive fractions [54].

Total Phenolic Contents: Phenolic compounds have been shown to possess important biological activities based on their structural characteristics [1-9]. There are concerns about using synthetic phenolic antioxidants such as butylated hydroxytoluene 
(BHT) and butylated hydroxyanisole (BHA) as food additives because of the reported negative effects on human health [52]. reported also that ethyl acetate fraction exhibited effective antioxidant and antiproliferative activities. The phenolic compounds identified in ethyl acetate fraction could be responsible for the activities. Highly significant quantities of total phenolic contents were found in crude extract of the two tested bacterial isolates equivalents of gallic acid (Table 4). The highest level of total phenolic contents was shown in extracts HA-MS-41 (3.238 $\pm 0.03 \mathrm{mg}$ gallic equivalent $/ \mathrm{ml}$ ). Whereas, the lowest value was shown in extract HA-MS-118 $(2.946 \pm 0.10 \mathrm{mg}$ gallic equivalent $/ \mathrm{ml}$ ).

Table 4: Total phenolic contents in the bacterial crude extracts expressed as $\mathrm{mg}$ gallic acid equivalent $/ \mathrm{ml}$.

\begin{tabular}{|c|c|}
\hline Extract & $\begin{array}{c}\text { Concentration of phenolic compounds (mg gallic } \\
\text { acid equivalent } / \mathbf{~ m l} \text { )* }\end{array}$ \\
\hline $\begin{array}{c}\text { HA-MS-41 } \\
\text { [JX484800] }\end{array}$ & $3.238 \pm 0.03$ \\
\hline $\begin{array}{c}\text { HA-MS-118 } \\
\text { [JX484801] }\end{array}$ & $2.946 \pm 0.10$ \\
\hline
\end{tabular}

${ }^{*}$ Results $=$ Mean $(n=3) \pm$ S.E.

Carotenoids Compounds and Retinol: Carotenoid contents tested in the bacterial extract were Xanthophyll, $\beta$-cryptoxanthin and $\beta$-carotene (Figure 5). Xanthophyll, beta-cryptoxanthin, beta- carotene (Table 5) were the major carotenoid compounds investigated in the present study. This group of compounds were reported to have strong antioxidant activity and biochemical properties influencing signaling pathways. Carotenoids was reported to prevent cancers and cardiovascular disorders. Besides, they may protect light-exposed tissues. Ample evidence is available in the literature suggesting carotenoids could possibly lower the risk of stroke, heart diseases, aging, vascular and other metabolic diseases [55]. The antioxidant potential of carotenoids is of particular significance to human health, due to the fact that losing antioxidant-reactive oxygen species balance results in "oxidative stress", a critical factor of the pathogenic processes of various chronic disorders. Carotenoids play a prominent role in protecting bodily cells and thereby act as powerful antioxidants. Moreover, they are proved to be vital for maintenance of proper eyesight and vision. It is now known that beta-carotene is the primary precursor for Vitamin A in humans.

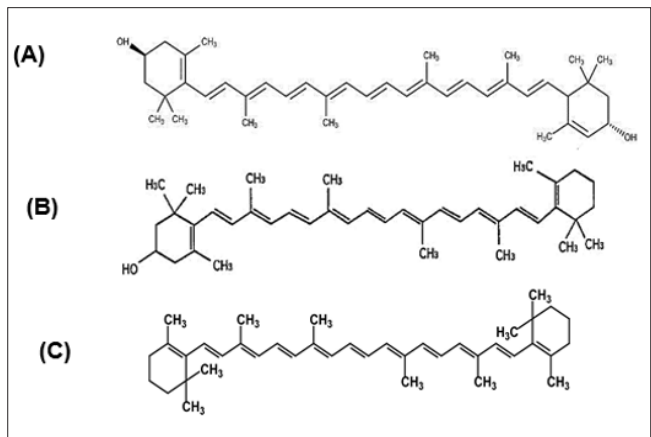

Figure 5: Structure of (A) Xanthophyll, (B) $\beta$-cryptoxanthin and (C) $\beta$-carotene.
Moreover, the positive roles of beta carotene in maintaining a proper vision and its role in other degenerative diseases are now known [56]. There is plenty of evidence now that suggests carotenoids or food products rich in carotenoids are indeed beneficial in the prevention of several types of cancers and malignancies. Certain types of cancers namely, the cancers of prostate gland, urinary bladder and of the colon respond to a natural substance called lycopene. Carotenoid compounds has been used to treat various disorders such as erythropoietic protoporphyria. It is believed to act as an antioxidant and an immune system booster. Carotenoid contents tested in the bacterial extracts were Xanthophyll, $\beta$-cryptoxanthin and $\beta$-carotene (Table 5). Carotenoid compounds significantly varied among the two bacterial extracts; the highest total carotenoid concentration was shown in extract HA-MS-41 $(1.165 \mu \mathrm{g} / \mathrm{ml})$. Whereas, lower values were measured in the HA-MS-118 [JX484801] extract $(0.185 \mu \mathrm{g} / \mathrm{ml})$ as shown in (Table 5).

Table 5: Concentrations of carotenoid compounds in the bacterial extracts HA-MS-41 and HA-MS-118.

\begin{tabular}{|c|c|c|c|c|}
\hline Extract no. & \multicolumn{3}{|c|}{ Carotenoids contents $(\mu \mathrm{g} / \mathrm{ml})$} \\
\hline & Xanthophyll & $\beta$-cryptoxanthin & $\beta$-carotene & Total \\
\hline $\begin{array}{c}\text { HA-MS-41 } \\
\text { [JX484800] }\end{array}$ & N.D. & 1.165 & N.D. & 1.165 \\
\hline $\begin{array}{c}\text { HA-MS-118 } \\
\text { [JX484801] }\end{array}$ & 0.185 & N.D. & N.D. & 0.185 \\
\hline
\end{tabular}

\section{Flavonoid Compounds}

The presence of two flavonoid compounds was tested in the two bacterial extracts; Catechin and Rutin (Figure 6). Rutin compound was below the detectable limit in the tested two extracts. The highest catechin values were found in HA-MS-118 [JX484801] extract $(8.652 \mathrm{mg} / \mathrm{ml})$ as shown in (Table 6).

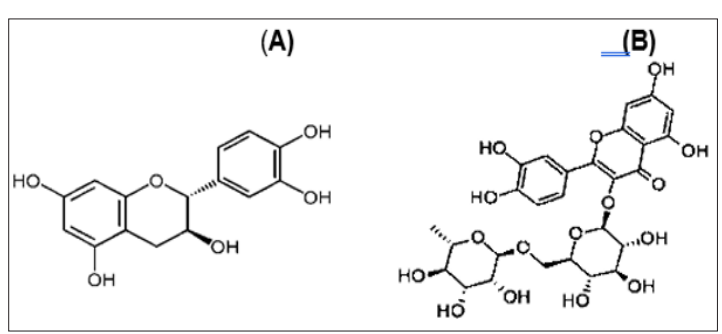

Figure 6: Structure of (A) Catechin and (B) Rutin.

Table 6: Concentrations of flavonoid in the tested bacterial extracts.

\begin{tabular}{|c|c|c|}
\hline Extract no. & $\begin{array}{c}\text { Concentration of } \\
\text { catechin }(\mathbf{m g} / \mathbf{m l})^{*}\end{array}$ & $\begin{array}{c}\text { Concentration of Rutin } \\
\mathbf{( m g / m l ) *}\end{array}$ \\
\hline $\begin{array}{c}\text { HA-MS-41 } \\
\text { [JX484800] }\end{array}$ & 5.430 & N.D. \\
\hline $\begin{array}{c}\text { HA-MS-118 } \\
\text { [JX484801] }\end{array}$ & 8.652 & N.D. \\
\hline
\end{tabular}

*N.D.: not detected. All analyses were mean of triplicate measurements. 
Total Flavonoid Content: Flavonoids, among other biologically active compounds such as sterols, alkaloids, saponins, glycosides, and tannins support the significant bioactivity exhibited by our crude extracts including inhibitory properties against a wide range of pathogens. There is an increasing interest toward research on flavonoids occurring in various sources of marine organisms including sponges and their associated bacteria due to their multipurpose health benefits such as free-radical scavenging property, anticancer activity, antiviral properties etc. [1-9,57]. Highly significant quantities of flavonoid contents were found in crude extract of the tested bacterial isolates equivalents of (+catechin). The highest level of total flavonoid content was shown

GC/MS Profiling for the Bacterial Crude Extract: The GC/ MS analysis of crude bacterial extracts as shown in (Figures 7 \& 8) indicates the presence of different bioactive components. The major components present in the ethyl acetate crude extracts are indicated in (Tables 8 \& 9). Sponges are important source of functional components for the development of new chemotherapeutic agents. Phytochemical investigation of the ethyl acetate extracts of the studied sponge-associated bacteria revealed the presence of various phytochemical such as phenolic compounds, flavonoids, saponins, steroids, tannins. The bioactive composition of the two studied bacterial extracts obtained by GC/MS analysis and their in HA-MS-41 extract. Whereas, the lowest value was shown in HAMS-118 extract (Table 7).

Table 7: Total flavonoid contents in the bacterial crude extracts expressed as $\mathrm{mg}$ catechin equivalent/ $\mathrm{ml}$.

\begin{tabular}{|c|c|}
\hline Extract no. & $\begin{array}{c}\text { Concentration of flavonoid compounds (mg catechin } \\
\text { equivalent } / \mathbf{~ m l )} *\end{array}$ \\
\hline $\begin{array}{c}\text { HA-MS-41 } \\
\text { [JX484800] }\end{array}$ & $5.0 \pm 0.23$ \\
\hline $\begin{array}{c}\text { HA-MS-118 } \\
\text { [JX484801] }\end{array}$ & $2.5 \pm 0.26$ \\
\hline
\end{tabular}

${ }^{*}$ Results $=$ Mean $(n=3) \pm$ S.E.

bioactivity profiling are shown in (Table 10). Data revealed that the crude extract HA-MS-41 contained the maximum diversity of identified compounds ( 9 compounds). Whereas, HA-MS-118 extract contained the lowest number of the identified compounds (4 compounds). All the revealed compounds were identified and confirmed the presence of a variety of natural product families including mono- and di-terpenes, steroids, phenolics, flavonoids, carotenoids and fatty acids. The occurrence of different bioactive compounds suggests a wide range of biological application of the tested extracts.

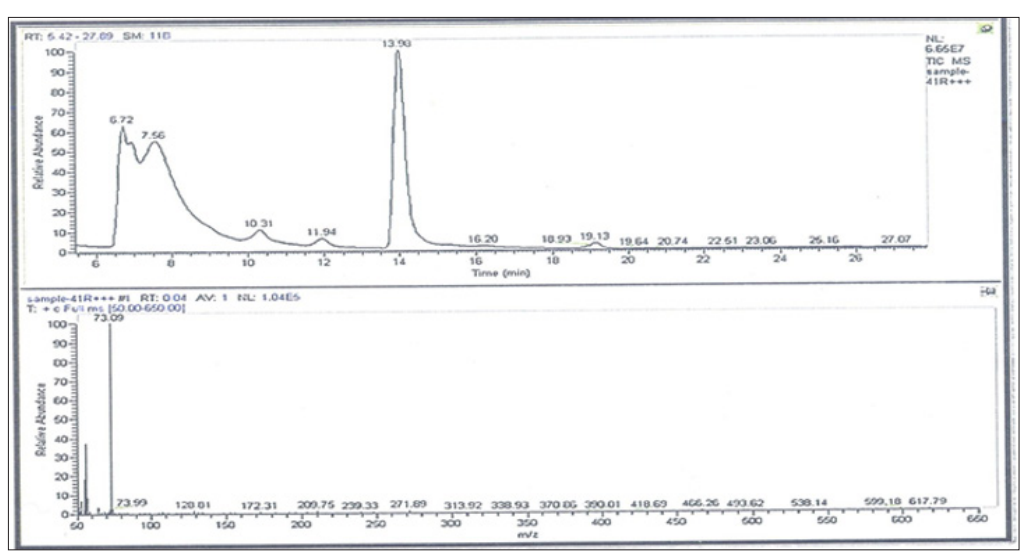

Figure 7: GC-MS patterns of the bacterial ethyl acetate extract HA-MS-41 [JX484800].

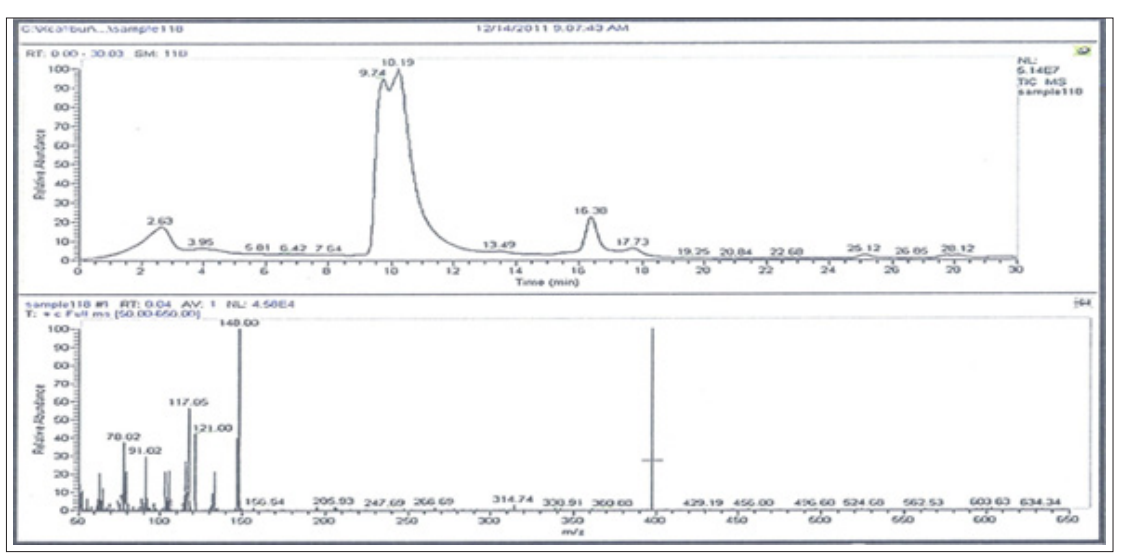

Figure 8: GC-MS patterns of the bacterial ethyl acetate extract HA-MS-118 [JX484801]. 
Table 8: Bioactive compounds identified in the crude extract HA-MS-41 [JX484800] by GC-MS.

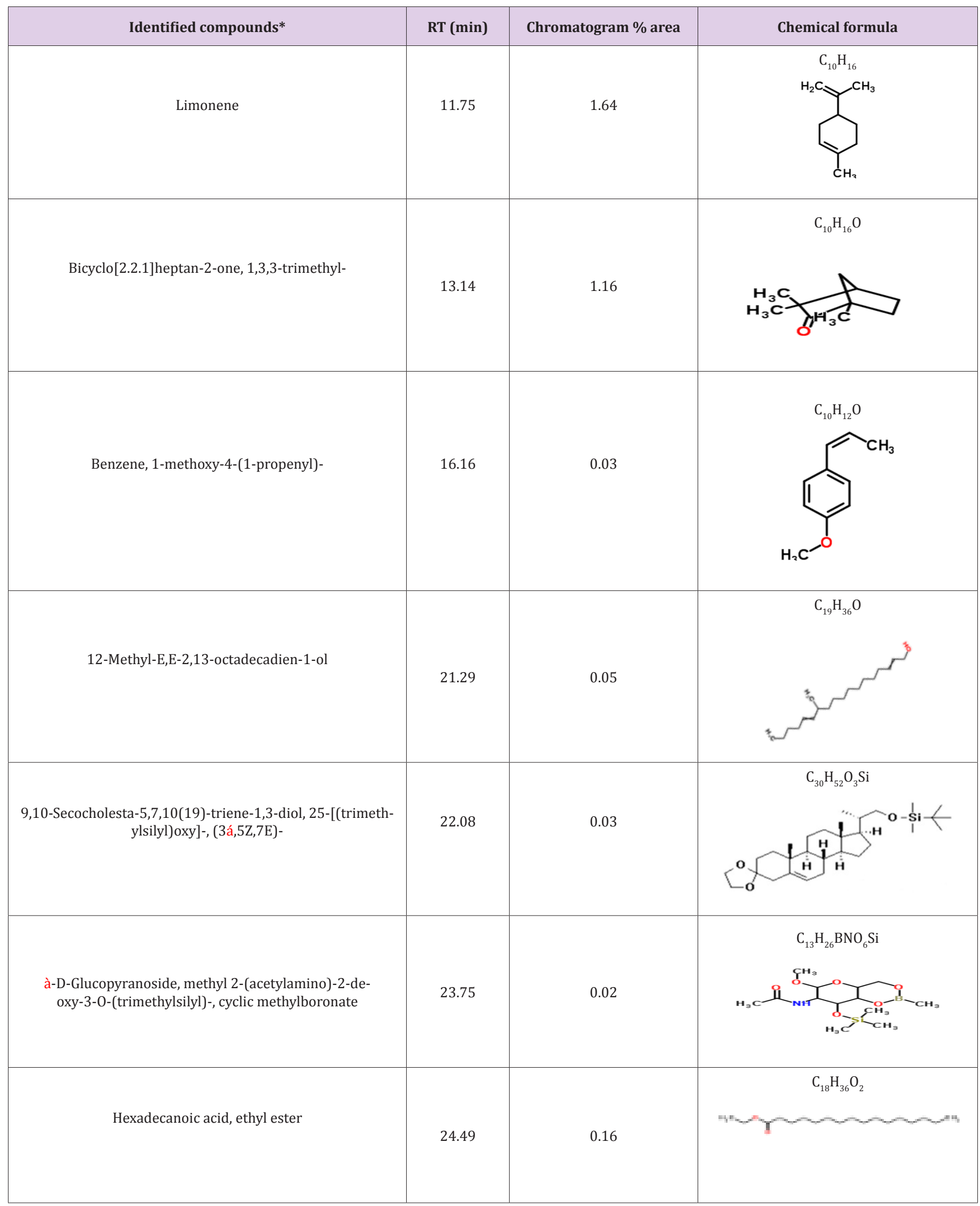




\begin{tabular}{|c|c|c|c|}
\hline $\begin{array}{l}\text { 3'8,8'-Trimethoxy-3-piperidyl-2,2'-binaphtha- } \\
\text { lene-1,1',4,4'-tetrone }\end{array}$ & 25.59 & 0.17 & $\mathrm{C}_{28} \mathrm{H}_{25} \mathrm{NO}_{7}$ \\
\hline Linoleic acid ethyl ester & 27.18 & 0.41 & $\mathrm{C}_{20} \mathrm{H}_{36} \mathrm{O}_{2}$ \\
\hline
\end{tabular}

*Number of identified compounds is (9).

Table 9: Bioactive compounds identified in the crude extract HA-MS-118 [JX484801] by GC-MS.

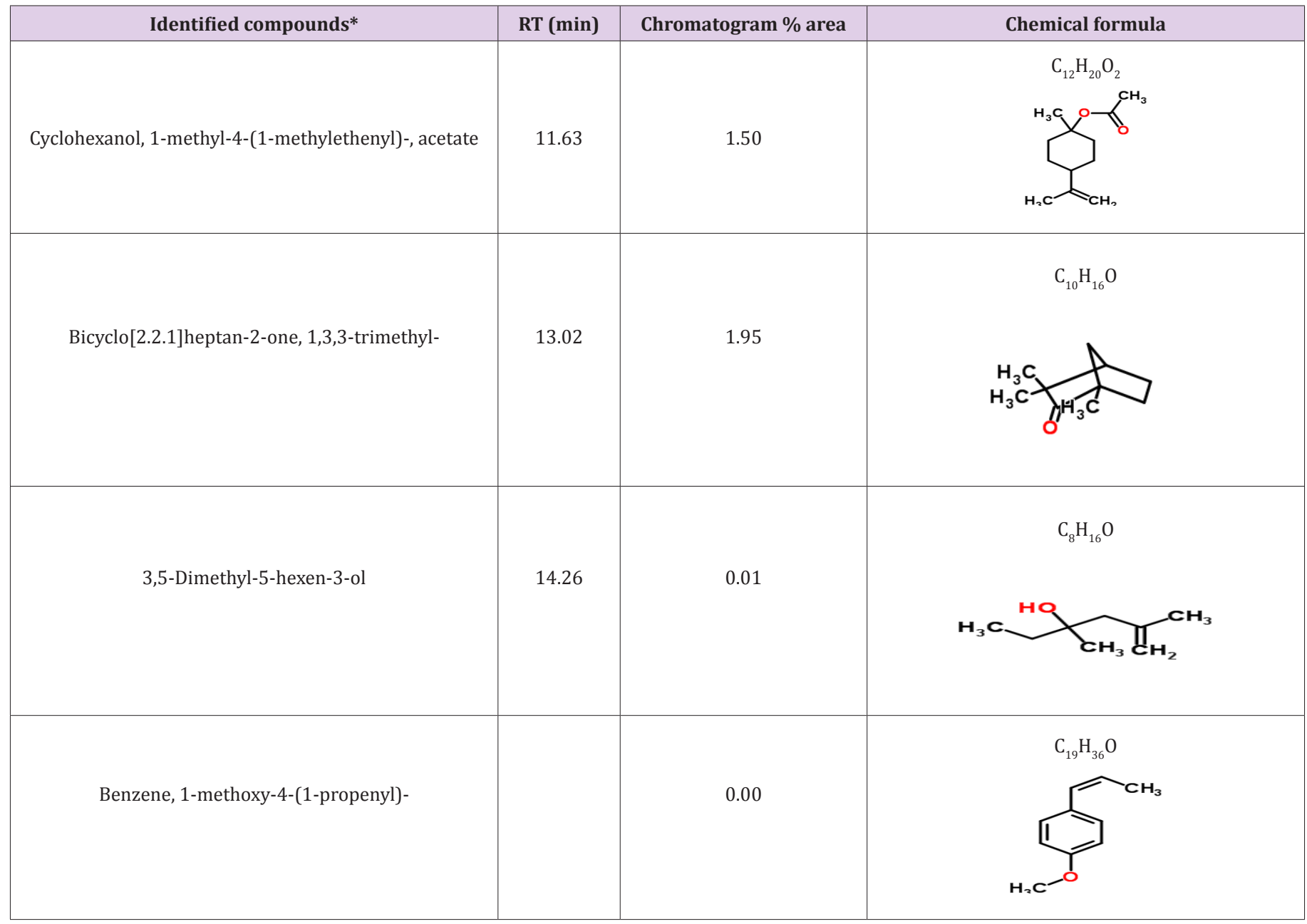

${ }^{*}$ Number of identified compounds is (4)

Table 10: Bioactive composition of the ten studied bacterial extracts obtained by GC/MS analysis and their bioactivity profiling.

\begin{tabular}{|c|c|c|c|c|c|}
\hline \multirow{2}{*}{ No. } & Compound & Chemical nature & \multicolumn{2}{|c|}{ Extract No. } & \multirow{2}{*}{ Beferences } \\
\cline { 3 - 5 } & Limonene & Monocyclic-mono-41 & HA-MS-118 & Anticancer antioxidant, growth \\
supplement, & + & [58-60] & Anti-inflammatory, anticancer, anti- \\
bacterial & $\begin{array}{c}\text { Bicyclo[2.2.1] heptan-2- } \\
\text { one, 1,3,3-trimethyl- }\end{array}$ & Sesquiterpene Hydrocarbons & + \\
\hline
\end{tabular}




\begin{tabular}{|c|c|c|c|c|c|c|}
\hline 3 & $\begin{array}{l}\text { Benzene, 1-methoxy-4-(1- } \\
\text { propenyl)-(Anethole) }\end{array}$ & Polyphenolic & + & + & $\begin{array}{l}\text { Antibacterial, antifungal, insecticidal, } \\
\text { antihelmintic, psychoactive effect }\end{array}$ & [63-66] \\
\hline 4 & $\begin{array}{c}\text { 12-Methyl-E,E-2,13-oct- } \\
\text { adecadien-1-ol (Vitamin } \\
\text { E- like) }\end{array}$ & Acyclic di-terpene & + & & Antimicrobial, antioxidant & {$[67,68]$} \\
\hline 5 & $\begin{array}{l}\text { à-D-Glucopyranoside, } \\
\text { methyl 2-(acetylami- } \\
\text { no)-2-deoxy-3-0-(trimeth- } \\
\text { ylsilyl)-, cyclic methylbo- } \\
\text { ronate }\end{array}$ & Flavonoids & + & & $\begin{array}{l}\text { Antibacterial, antifungal, antiviral, } \\
\text { Antioxidants }\end{array}$ & [9] \\
\hline 6 & $\begin{array}{l}\text { Hexadecanoic acid, ethyl } \\
\text { ester }\end{array}$ & $\begin{array}{l}\text { Aliphatic carboxylic hudrocar- } \\
\text { bons (Fatty acid esters) }\end{array}$ & + & & $\begin{array}{c}\text { Antibacterial, antifungal, Antioxidant, } \\
\text { HypocholesterolemicNematicide, } \\
\text { Pesticide, Lubricant, Antiandrogenic, } \\
\text { Flavor, Hemolytic 5-Alpha reductase } \\
\text { inhibitor }\end{array}$ & [69] \\
\hline 7 & Linoleic acid ethyl ester & $\begin{array}{l}\text { Aliphatic carboxylic hudrocar- } \\
\text { bons (Fatty acid esters) }\end{array}$ & + & & $\begin{array}{l}\text { Insecticide, pesticide, cosmetics and } \\
\text { personal care products }\end{array}$ & [70] \\
\hline 8 & $\begin{array}{l}\text { Cyclohexanol, 1-meth- } \\
\text { yl-4-(1-methylethenyl)-, } \\
\text { acetate }\end{array}$ & Cyclic terpenoids & + & & Antifungal & [71] \\
\hline 9 & 3,5-Dimethyl-5-hexen-3-ol & Terpenes & & + & Anticancer, antiinflammatory & [72] \\
\hline 10 & $\begin{array}{l}\text { 3',8,8'-Trimethoxy-3-piper- } \\
\text { idyl-2,2'-binaphtha- } \\
\text { lene-1,1,4,4'-tetrone }\end{array}$ & Alkaloids & + & & Antisickling & [73] \\
\hline 11 & Estragole & Phenyl propene & & + & $\begin{array}{l}\text { Anesthetic; Anticonvulsant; Myore- } \\
\text { laxant; }\end{array}$ & [74] \\
\hline \multicolumn{3}{|c|}{ Total number of identified compounds } & 9 & 4 & & \\
\hline
\end{tabular}

FT-IR Spectroscopy: FTIR spectroscopy was useful for the compound identification and when run under IR region in the range of 400-4000 cm-1 there was a variation in the peaks in the tested bacterial extracts. FTIR allows detecting the whole range of infrared spectrum simultaneously providing speed and accuracy in measurements of biological specimens. (Figures $9 \& 10$ ). Based on the functional group analysis, the bacterial extracts don't contain any toxic compounds. Furthermore, The IR analysis gave results that suggest the presence of different functional groups ranging from 0-H stretching, hydroxyl (3472.7-3362.6 $\left.\mathrm{cm}^{-1}\right), \mathrm{C}-\mathrm{H}$ stretching, alkyl (2933.7-1460.6 $\left.\mathrm{cm}^{-1}\right), \mathrm{C}=\mathrm{C}$ stretching $\left(1667.3-1414.4 \mathrm{~cm}^{-1}\right)$, C- 0 bending, alcohols, ethers, esters, carboxylic acid and anhydrides (1382-1041.4 $\mathrm{cm}^{-1}$ ), C=0 stretching, carboxylic, carbonyl (1923.7$1721.3 \mathrm{~cm}^{-1}$ ) and $\mathrm{C}-\mathrm{N}$ bending, alkaloids (1405.2-1234.6 $\left.\mathrm{cm}^{-1}\right)$.

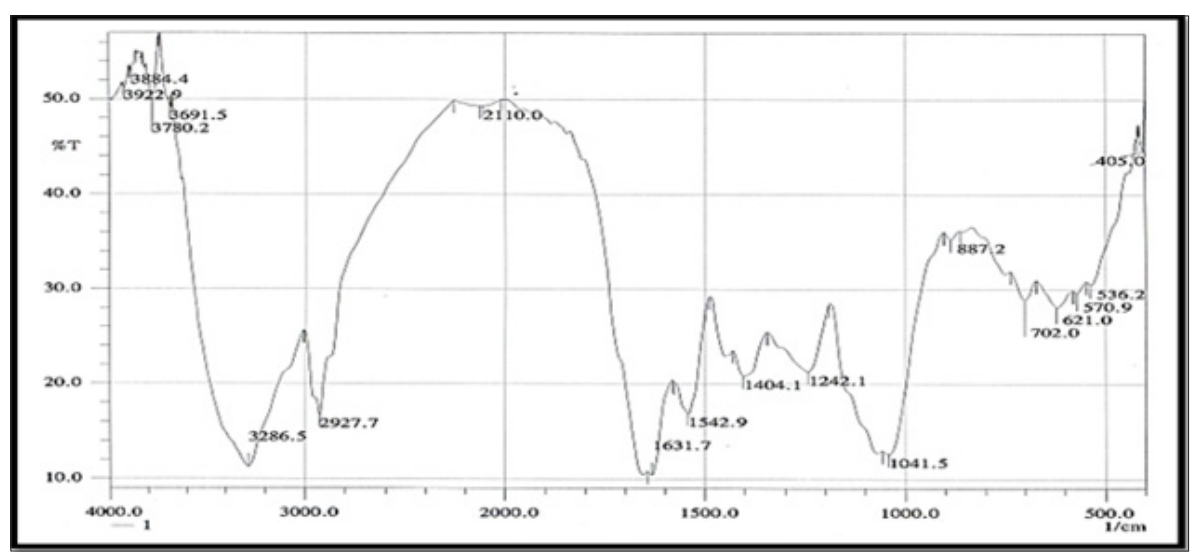

Figure 9: FTIR analysis of the ethyl acetate crude extract HA-MS-41[JX484800]. 


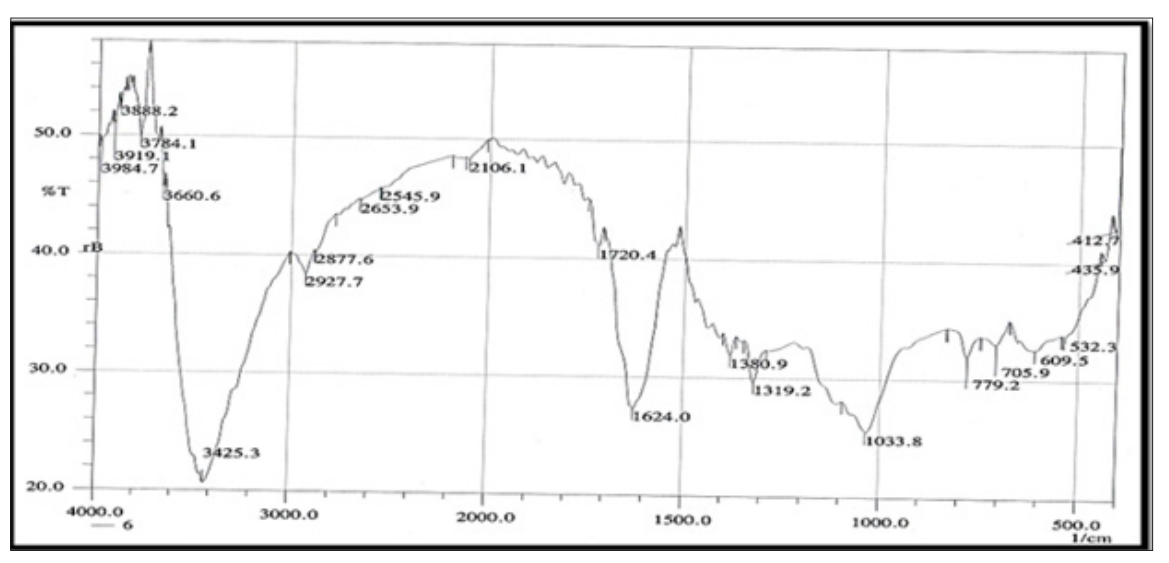

Figure 10: FTIR analysis of the ethyl acetate crude extract HA-MS-118[JX484801].

Elemental Analysis: Elemental analysis of the tested extracts were presented in (Tables 11 \& 12). The results of the elemental analysis of the ethyl acetate extract of the two tested bacteria indicated that the bacterial extracts contained major elements like $\mathrm{Na}, \mathrm{Mg}, \mathrm{Al}, \mathrm{Si}, \mathrm{S}, \mathrm{K}, \mathrm{Ca}, \mathrm{P}$ and $\mathrm{Cl}$. Besides, the major elemental constituents in all living organisms; $\mathrm{C}, \mathrm{N}$ and $\mathrm{O}$. The results showed considerable concentrations of many halides ( $\mathrm{Fe}, \mathrm{Cu}, \mathrm{Zn}$ and $\mathrm{Br}$ ). Extracts number HA-MS-118 showed the highest concentration percentages of Br (2.367\%), Fe (0.093\%), whereas extract HA-MS-41 showed the highest concentrations of $\mathrm{Na}(1.330 \%)$ and $\mathrm{K}(2.297 \%)$ (Table 11). Elements iron (Fe), copper (Cu), cobalt(Co), nickel (Ni), zinc (Zn), manganese (Mn), magnesium (Mg), molybdenum (Mo), chronium (Cr), vanadium (V), lithium (Li), selenium (Se), flourine (F) and iodine (I) play both curative and preventive roles in fighting diseases of animals, plants and human beings [75]. The tested two bacterial extracts had high $\mathrm{Ca}$ and $\mathrm{Mg}$ contents. Calcium functions as a constituent of bones and teeth, regulation of nerve and muscle function. In blood coagulation, calcium activates the conversion of prothrombin to thrombin and also takes part in milk clotting. It plays a vital role in enzyme activation. It regulate heart rhythm, helps in normal blood clotting, maintain proper nerve and muscle functions and lower blood pressure.

Table 11: Elemental analysis of the ethyl acetate extract of the HA-MS-41 [JX484800] bacterial isolate.

\begin{tabular}{|c|c|c|c|c|c|}
\hline Element & Percentage (\%) & Element & Percentage (\%) & Element & Percentage (\%) \\
\hline $\mathrm{O}$ & 53.097 & $\mathrm{Cl}$ & 0.907 & $\mathrm{Na}$ & 1.330 \\
\hline $\mathrm{C}$ & 26.843 & $\mathrm{~S}$ & 0.857 & $\mathrm{Al}$ & \\
\hline $\mathrm{N}$ & 13.523 & $\mathrm{P}$ & 1.143 & & \\
\hline $\mathrm{Ca}$ & 0.260 & $\mathrm{Si}$ & 0.133 & & \\
\hline $\mathrm{K}$ & 1.467 & $\mathrm{Mg}$ & 0.137 & & \\
\hline
\end{tabular}

Table 12: Elemental analysis of the ethyl acetate extract of the HA-MS-118 [JX484801] bacterial isolate.

\begin{tabular}{|c|c|c|c|c|c|}
\hline Element & Percentage (\%) & Element & Percentage (\%) & Element & Percentage (\%) \\
\hline $\mathrm{O}$ & 41.373 & $\mathrm{Ca}$ & 0.117 & $\mathrm{Mg}$ & 0.100 \\
\hline $\mathrm{C}$ & 34.627 & $\mathrm{~K}$ & 2.297 & $\mathrm{Na}$ & 1.053 \\
\hline $\mathrm{N}$ & 17.173 & $\mathrm{Cl}$ & 0.270 & & \\
\hline $\mathrm{Br}$ & 2.367 & $\mathrm{~S}$ & 0.370 & & \\
\hline $\mathrm{Fe}$ & 0.093 & $\mathrm{P}$ & 0.230 & & \\
\hline
\end{tabular}

Mg is also an essential activator for the phosphate-transferring enzymes myokinase, diphophospyridine nucleotide kinase, and creatine kinase. It also activates pyruvic acid carboxylase, pyruvic acid oxidase, and the condensing enzyme for the reactions in the citric acid cycle. It is also a constituent of bones, teeth, enzyme cofactor, kinases, etc. [76]. In the current study, among the various minerals potassium was observed also in high level in both tested two extracts. Without potassium which is an essential for the transport for nutrients inside the cell, nutrients could not be able to enter into the cell that leads cell death. Potassium is followed by phosphorous in the tested two extracts. Sodium, on the other hand, is the principle extracellular cation used for osmoregulation in inter modular fluid of human body was measured in the two tested extracts. The highest Na content was obtained from the HA-MS-41 bacterial isolate.

Silicon which is also another important element to prevent the hardening blood veins and arteries was observed in the HA-MS-41 bacterial isolate, but not in the HA-MS-118 bacterial isolate. Al was measured in the HA-MS-41 bacterial isolate, but not in the HA- 
MS-118 bacterial isolate. In the meantime, $\mathrm{Br}$ and Fe were found in the HA-MS-118 bacterial isolate, but not in the HA-MS-41 bacterial isolate (Tables 11 \& 12). Iron is an essential element because it is important in several enzyme reactions as co-factors. It has an oxidizing effect, it acts as astringent. The current study indicated the presence of considerable amounts of halogens such as chlorine and bromine. The presence of halogen substituents in many natural products profoundly influences their biological activity. Chemical structures of marine products often differ from terrestrial secondary metabolites in being halogenated with bromine and/or chlorine. Chlorine is found in the HA-MS-118 bacterial extract.

Unlike terrestrial organisms, marine organisms often produce halogenated secondary metabolites, particularly alkaloids [77]. The results of the current study showed that the highest bacterial extracts in bromine content was HA-MS-118. It has been suggested that marine life produces most of the 4,000known natural organohalogens, and almost all of the 2,100 natural organobromine compounds are found in marine organisms [78]. Halogen containing secondary metabolites exhibit interesting biological effects, such as antibiotic, anticancer and others. On the other hand, (Tables $11 \& 12$ ) showed that the two tested bacterial extracts contained sulfur in variable amounts, among the highest bacterial extracts in sulfur contents was the HA-MS-41 bacterial isolate. Sulfur in the form of organic and inorganic compounds is always present in all living organisms and is an important biogenic element. The average content of sulfur is relatively higher in marine organisms. On average natural product contain less nitrogen, sulfur, and halogen atoms but in marine natural product there is higher ratio of this constituent. Moreover, sulfur containing phenolic compounds can be reasonably speculated as strong antiinflammatory and antioxidant agents. Activity of sulfur-containing phenolic antioxidants in vivo is mediated by their effect on redoxsensitive transcription factors [79]. Conclusively, the presence of these elements in the tested extracts marks its usage in therapeutic purposes and may remark the tested bacterial extracts in the current study as promising bioactive materials.

\section{Biochemical Assays}

Antioxidant Capacity: Living cells in the human body continuously produce reactive oxygen species and free radicals and are controlled by body enzymes. Over production of either free radicals, reactive oxygen species or failure in the defense mechanisms result in severe damage to cells and tissues leading to non-communicable chronic diseases, specifically cancer [80]. Antioxidants are capable of inhibiting the oxidation that produces free radicals. In turn, these radicals can start chain reactions that damage cells. Antioxidants terminate these chain reactions by removing free radicals intermediates and inhibit other oxidation reactions [81]. In the current study, the levels of total antioxidant capacity (TAO) were measured in the bacterial extracts using DPPH, ABTS, NO and Phosphomolybdenum assays. The present results revealed a potential antioxidant activity of the two tested bacterial extracts.

DPPH Scavenging Activity: The results of DPPH test indicated that IC50 values of ethyl acetate extracts HA-MS-41 and HA-MS-118 bacterial isolate were lower than the standard used for the assay; ascorbic acid (IC50 = $2.52 \mathrm{mg} / \mathrm{ml}$ ). DPPH scavenging activity in terms of IC50 values was shown to be high in case of extract HAMS-41 (1.045 mg/ml) and in case of extract HA-MS-118 (1. 473mg/ $\mathrm{ml}$ ). This may be due to the presence of some potent antioxidant compounds such as limonene, amiodarone and 3',8,8'-Trimethoxy3-piperidyl-2,2'-binaphthalene-1,1',4,4'-tetrone which are powerful antioxidants and have good radical scavenging activities. This finding is also compatible with the total phenolic and flavonoids contents of the two tested extracts (Table 13).

Table 13: Total antioxidant of the examined two extracts using DPPH assay.

\begin{tabular}{|c|c|c|}
\hline \multirow{2}{*}{ Extract concentration $(\mathbf{m g} / \mathbf{m l})$} & \multicolumn{2}{|c|}{ TEAC/mM equivalent Ascorbic acid* } \\
\cline { 2 - 3 } & HA-MS-41 [JX484800] & HA-MS-118 [JX484801] \\
\hline 30 & $94.69 \pm 0.01$ & $91.74 \pm 0.04 \pm 0.005$ \\
\hline 6 & $93.13 \pm 0.001$ & $85.93 \pm 0.07$ \\
\hline 1.2 & $93.95 \pm 0.03$ & $66.49 \pm 0.03$ \\
\hline 0.24 & $88.88 \pm 0.12$ & $29.69 \pm 0.0 .22$ \\
\hline 0.048 & $50.53 \pm 0.49$ & $9.79 \pm 0.11$ \\
\hline 0.01 & $48.71 \pm 0.78$ & 1.473 \\
\hline
\end{tabular}

*Data are mean \pm SD

Nitric Oxide (NO) Assay: Interestingly, the antioxidant potency of the tested bacterial extracts was also measured by NO assay; since NO- has a damaging effect as RNS in in vivo system. Nitric oixde (NO-) is radical compound produced during the transformation of $\mathrm{L}^{-}$arginine to citrulline by nitric oxide synthase (NOS). Nitric oxide functions as the effecter molecule for macrophage-mediated cytotoxicity and has also been recognized to inhibit mitochondrial respiration and DNA synthesis. Nitric oxide recently raised a lot of interests as a suppressive factor that inhibits anti-tumor immune response. Readings are based on the colorimetric change, which occurs when naphthyl ethylenediamine is added to the by-product of reaction between sulfanilamide and nitrite. Highly significant TEAC value was obtained (Table 14). Percentage inhibition gradually increased with increase in concentration. IC50 values of 
the antioxidant activity of bacterial extracts using NO assay for the tested two extracts were 5.98 and $6.22 \%$. That was in agreement with the high phenolic and flavonoid compounds present in the tested extracts [81].

Table 14: Total antioxidant of the examined two extracts using Nitric oxide (NO) assay.

\begin{tabular}{|c|c|c|}
\hline \multirow{2}{*}{ Extract concentration (mgLml) } & \multicolumn{2}{|c|}{ TEAC/mM equivalent Ascorbic acid* } \\
\cline { 2 - 3 } & HA-MS-41 [JX484800] & HA-MS-118 [JX484801] \\
\hline 30 & $72.15 \pm 0.013$ & $30.47 \pm 0.006$ \\
\hline 6 & $59.91 \pm 0.005$ & $39.48 \pm 0.111$ \\
\hline 1.2 & $31.195 \pm 0.004$ & $33.27 \pm 0.01$ \\
\hline 0.24 & $23.36 \pm 0.003$ & $32.52 \pm 0.001$ \\
\hline 0.048 & $21.4 \pm 0.013$ & $31.5 \pm 0.002$ \\
\hline 0.01 & $18.66 \pm 0.027$ & $6.222 \pm 0.012$ \\
\hline $\mathrm{IC}_{50}(\mathrm{mg} / \mathrm{ml})$ & $5.98 \pm 0.003$ & \\
\hline
\end{tabular}

*Data are mean \pm SD

ABTS+ assay: DPPH assay was confirmed by ABTS assay. Highly significant TEAC values were obtained in the tested bacterial extracts (Table 15). Percentage inhibition gradually increased with increase in concentration. The results of the current study cleared out that the ABTS assay gave completely different results for the antioxidant activity measured in the tested two extracts (Table 15). The percentage inhibition of the HA-MS-41 [JX484800] was higher (IC50 $=3.40 \mathrm{mg} / \mathrm{ml}$ ) than that of the HA-MS-118 [JX484801] extract (IC50 $=1.64 \mathrm{mg} / \mathrm{ml}$ ) revealing much higher antioxidant capacity. The high potency of the two extracts as strong antioxidant capacity may returns to its high phenolic contents $(4.991 \& 10.369$ $\mu \mathrm{g} / \mathrm{ml}$, respectively), specially caffeic acid (1.165 $5.642 \mu \mathrm{g} / \mathrm{ml}$, respectively).

Table 15: Total equivalent antioxidant activity and IC50 values of the bacterial extracts using ABTS+ assay.

\begin{tabular}{|c|c|c|c|c|}
\hline Extract no. & Conc. $(\mathrm{mg} / \mathrm{ml})$ & \% inhibition & mM Trolox equivalent & $\mathrm{IC}_{50}(\mathrm{mg} / \mathrm{ml})$ \\
\hline \multirow{6}{*}{$\begin{array}{l}\text { HA-MS-41 } \\
\text { [JX484800] }\end{array}$} & 30 & 94.34 & 8.53 & \multirow{6}{*}{3.40} \\
\hline & 6 & 68.77 & 5.67 & \\
\hline & 1.2 & 39.8 & 2.43 & \\
\hline & 0.24 & 25.72 & 0.86 & \\
\hline & 0.048 & 22.16 & 0.46 & \\
\hline & 0.01 & 20.54 & 0.28 & \\
\hline \multirow{6}{*}{$\begin{array}{l}\text { HA-MS-118 } \\
\text { [JX484801] }\end{array}$} & 30 & 88.51 & 7.88 & \multirow{6}{*}{1.64} \\
\hline & 6 & 66.02 & 5.36 & \\
\hline & 1.2 & 63.59 & 5.09 & \\
\hline & 0.24 & 52.10 & 3.81 & \\
\hline & 0.048 & 37.80 & 2.22 & \\
\hline & 0.01 & 26.37 & 0.93 & \\
\hline
\end{tabular}

Phosphomolybdenum assay: Total antioxidant capacity of the ethyl acetate extracts using the Phosphomolybdenum expressed as the number of equivalents of ascorbic acid and based on the reduction of Mo (VI) to Mo (V) by the antioxidant compound and the formation of a green phosphate/Mo (V) complex with a maximal absorption at $695 \mathrm{~nm}$ revealed that the antioxidant activity of the tested two extracts exhibit increasing trend with the increasing concentration of the bacterial extract (Table 16). Addition of various concentrations of the extracts showed that extract HA-MS-118 [JX484801] (37.75 $\pm 9.23 \mathrm{mM}$ equivalent ascorbic acid at extract concentration $30 \mathrm{mgml}$ ) was more effective to reduce Mo (VI) to Mo (V), while the lowest effects were shown by HA-MS-41 [JX484800] (25.537 $\pm 0.74 \mathrm{mM}$ equivalent ascorbic acid at extract concentration $30 \mathrm{mgml}$ ) (Table 16). The reduction of Mo (VI) to Mo (V) suggested the presence of effective antioxidants in HA-MS-118 [JX484801] and HA-MS-41 [JX484800] bacterial extracts (Table 16).

Table 16: Total antioxidant of the examined two extracts using phosphomolybdenum assay.

\begin{tabular}{|c|c|c|}
\hline \multirow{2}{*}{ Extract concentration $(\mathbf{m g} / \mathbf{m l})$} & \multicolumn{2}{|c|}{ TEAC/mM equivalent Ascorbic acid* } \\
\cline { 2 - 3 } & HA-MS-41 [JX484800] & HA-MS-118 [JX484801] \\
\hline 30 & $25.537 \pm 0.74$ & $37.75 \pm 9.23$ \\
\hline 6 & $6.431 \pm 0.097$ & $7.176 \pm 3.76$ \\
\hline 2.5 & $2.651 \pm 0.035$ & $1.743 \pm 0.13$ \\
\hline
\end{tabular}

Cite this article: Mohamed A S, Nihad M Abdel M, Galila A Y, Haiam M Aboul E. Isolation, Phylogenetic Analysis of the Microbial Community Associated with the Red Sea Sponge Ircinia Echinata and Biological Evaluation of their Secondary Metabolites. Biomed J Sci \& Tech Res 12(2)- 


\begin{tabular}{|c|c|c|}
\hline 0.24 & $0.618 \pm 0.003$ & $0.374 \pm 0.019$ \\
\hline 0.048 & $0.537 \pm 0.022$ & $0.157 \pm 0.001$ \\
\hline 0.01 & $0.401 \pm 0.001$ & $0.0 .144 \pm 0.00$ \\
\hline
\end{tabular}

*Data are mean \pm SD

\section{Anticancer Assays}

Cytotoxicity Studies: For many years past, the cytotoxic actions of natural products were regarded as the first step in identifying cancer chemotherapeutic drugs. In vitro cytotoxicity assays are a potentially useful tool in the study of toxic compounds of complex mixtures. A significant number of marine compounds have shown potential anticancer activities against the different hallmarks of cancer, such as cell growth inhibition, antimitotic activity (antitubulin effects), apoptosis and/or autophagy induction, and migration, invasion or metastasis inhibition. For most of the isolated compounds and their semisynthetic derivatives, the reported activities have been observed in vitro, but a significant number of these compounds, i.e., more than twenty, are either approved or in clinical phase. MNPs exhibit extensive chemical variability and complexity and include alkaloids, polyketides, terpenes, peptides and carbohydrates. Although marine resources are also limited, sourcing issues should be solved in the future by using aquaculture and biotechnology processes and the improvement of chemical synthesis in order to provide sufficient amounts of compounds for research purposes or pharmaceutical development [82].

In the present study, the tested crude extracts of the bacterial isolates, each at six different concentrations $(50-1.56 \mu \mathrm{g} / \mathrm{ml})$, were used to screen the cytotoxicity against breast cancer (MCF7), colon cancer (HCT) and hepatocellular carcinoma (HepG2). It has been observed that the two extracts obtained from the tested sponge associated bacteria were toxic against those carcinoma cells (Table 17). The present results revealed that the maximum cell growth inhibitory effects of bacterial crude extracts against the tested cancer cell lines; HepG2; HCT and MCF-7 were obtained from extract HA-MS-118 (IC50= 36.5; 23.6; $11.9 \mu \mathrm{g} / \mathrm{ml}$, respectively). While, the minimum IC50 values against all the tested cancer cell lines HepG2; HCT and MCF-7 were obtained from the extract HA-MS-41 (IC50 $=22.7 ; 14.6 ; 12.2 \mu \mathrm{g} / \mathrm{ml}$, respectively (Figures $11 \& 12$ ) show the cytotoxicity trends of the bacterial extracts against the three cancer cell lines. These values represent in all cases a comparable high toxicity to many other marine bacteria crude extracts Figures The results of this study are in good agreement with previous findings reported by Abdelnasser et al. [83]. Interestingly, the comparatively high cytotoxic effect of the extract HA-MS-118 may be due to its high Boron and Fe contents along with the presence of reasonable amounts of different biologically active compounds. Moreover, data obtained from cytotoxicity test against cancer cell lines are compatible with the high amounts of phenolic, flavonoids, alkaloids and other anticancer natural compounds shown in the tested extracts.

Table 17: $\mathrm{IC}_{50}$ values of the bacterial extracts against the three tested cancer cell lines.

\begin{tabular}{|c|c|c|}
\hline \multirow{2}{*}{ Cancer cell line } & \multicolumn{2}{|c|}{ IC $_{50}$ of the bacterial crude extracts $(\boldsymbol{\mu g} / \mathbf{m l})$} \\
\cline { 2 - 3 } & \multicolumn{2}{|c|}{ Bacterial extract } \\
\cline { 2 - 3 } & HA-MS-41 & HA-MS-118 \\
\hline HepG2 & 22.7 & 36.5 \\
\hline HCT & 14.6 & 23.6 \\
\hline MCF-7 & 12.2 & 11.9 \\
\hline
\end{tabular}

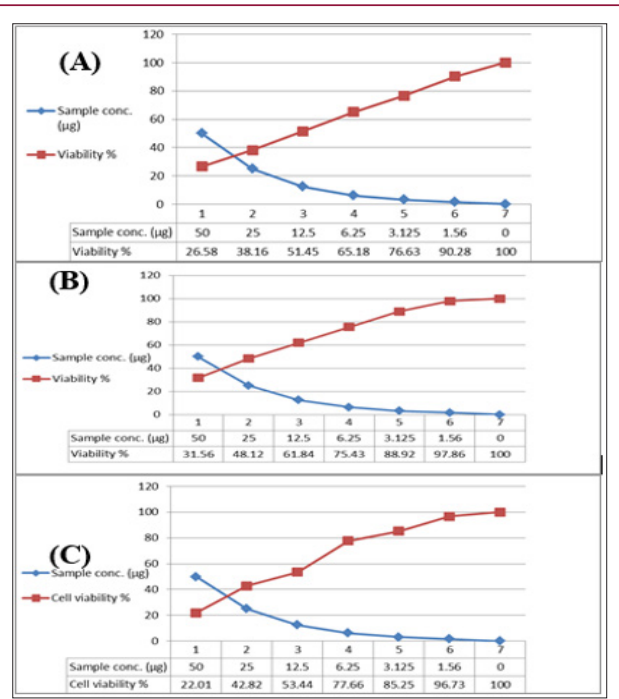

Figure 11: Cytotoxic activity of extract HA-MS-41 against cancer cell lines; (A): MCF-7, (B): HepG and (C): HCT. 


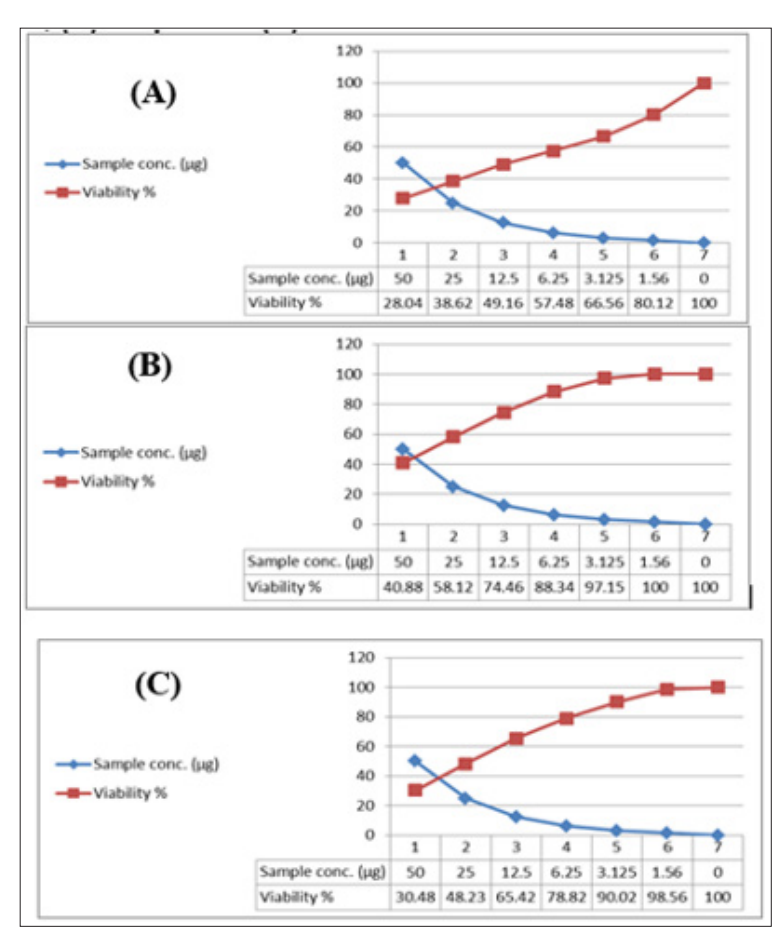

Figure 12: Cytotoxic activity of extract HA-MS-118 against cancer cell lines; (A): MCF-7, (B): HepG and (C): HCT.

\section{Protein kinase Inhibitory Effect}

Previous cytotoxicity data were confirmed by a specialized screening of anticancer test; protein kinase inhibition effect. Protein tyrosine kinases (PTKs) are key enzymes in many signal transduction pathways and play a crucial role in many cell regulatory processes. Functional perturbation of some of the enzymes results in a variety of diseases including cancer and inflammation $[84,85]$. This study (Table 18) revealed that the highest PTK inhibition activity was obtained from extract HA-MS 118 (inhibition \% = $94.24 \pm 1.15)$. Whereas, the lowest inhibition activity was obtained from extract HA-MS 41 (inhibition $\%=87.93 \pm 0.51$ ) indicating high potency of inhibition activity. This may be due to the presence of natural product compounds such as flavonoids and alkaloids which are considered as protein kinase inhibitors [86]. It has been stated that marine sponge metabolites had proven to be extremely potent against a range of kinase targets heavily involved in an increasing list of disease mechanisms including cancer, Alzheimer's disease and atherosclerosis $[82,87,88]$.

Table 18: Effect of the HA-MS-41 and HA-MS-118 bacterial extracts on protein kinase inhibition.

\begin{tabular}{|c|c|}
\hline Extract & Inhibition $\%$ * \\
\hline HA-MS-41 & $87.93 \pm 0.51$ \\
\hline HA-MS-118 & $94.24 \pm 1.15$ \\
\hline
\end{tabular}

*Data are means \pm S.D.

\section{Conclusion}

In continued search in our laboratory for novel microbial secondary metabolites, bacterial strains were screened. This has resulted in isolation of a promising strain of Proteobacteria species from the Red Sea sponge Ircinia echinata. Two tested isolates, HA-MS-41 and HA-MS-118 showed antioxidant activity as well as cytotoxicity against three established cancer cell lines. This study cleared out the importance of bioprospecting studies of marine biodiversity for bioactive natural compounds discovery and development of new drugs. The active extracts deserve special attention in further studies on the isolation and structure determination, as well as more refined biological assays; since clearly, the bacteria associated Red Sea sponge assayed could play an important source for the development of new biotechnological products.

\section{Acknowledgement}

All the authors gratefully acknowledge Dr. Asmaa Nabiel Adam and Mr. Mohamed Adel from the National Institute of Oceanography and Fisheries, Egypt. for their help and technical support. The authors also acknowledge with thanks Prof. Michele Kelly at National Institute of Water and Atmospheric Research (NIWA) Ltd., Auckland, New Zealand, for his help in sponge identification.

\section{References}

1. Abdel Monein NM, Al Assar SA, Shreadah MA, Nabil Adam A (2017) Isolation, Identification and Molecular Screening of Psudomance Sp. Metabolic pathways NRPs and PKS associated with the Red Sea sponge, Hyrtios aff. Erectus, Egypt. Journal of pure \& Applied Microbiology 11(3): 1299-1311.

2. Abdel Monein NM, Shreadah MA, Al Assar SA, Nabil Adam A (2017) Protective role of antioxidants capacity of Hyrtios aff. Erectus sponge extract against mixture of persistent organic pollutants (POPs)-induced hepatic toxicity in mice liver: biomarkers and ultrastructural study. Environmental Science and Pollution Research 24(27): 22061-22072.

3. Abd El Moneam NM, Sheradah MA, Al Assar SA, Nabil Adam A (2017) Protective role of antioxidant capacity of Hyrtios aff. Erectus sponge extract against mixture of Persistent organic pollutant (POPs)-induced 
hepatic toxicity in liver mice: Biomarkers and Ultra-structural study. Environmental Science and Pollution Research 24(1).

4. Abdel Monein NM, Yacout GA, Aboul Ela HM, Shreadah MA (2017) Hepatoprotective Activity of Chitosan Nanocarriers Loaded With the Ethyl Acetate Extract of Astenotrophomonas sp. Bacteria Associated with the Red Sea Sponge Amphimedon Ochracea In $\mathrm{CCl}_{4}$ Induced Hepatotoxicity in Rats. Advances in Bioscience and Biotechnology 8(1): 27-50.

5. Abdel Monein NM, Yacout GA, Aboul Ela HM, Shreadah MA (2017) Hepatoprotective Activity of Chitosan Nanocarriers Loaded with the Ethyl Acetate Extract of Astenotrophomonas sp. Bacteria Associated with the Red Sea Sponge Amphimedon Ochracea In $\mathrm{CCl}_{4}$ Induced Hepatotoxicity in Rats. Advances in Bioscience and Biotechnology 8(1) 27-50.

6. Abd El Moneam NM, Sheradah MA, Al Assar SA, De Voogd NJ, Nabil Adam A (2018) Hepatoprotective effect of Red Sea sponge extract against the toxicity of a real-life mixture of persistent organic pollutants. Biotechnology \& Biotechnological Equipment 32 (3): 734-743.

7. Sheradah MA, Abd El Moneam NM, Al Assar SA, Nabil Adam A (2017) The Ameliorative Role of a Marine Sponge Extract against Mixture of Persistent Organic Pollutants induced Changes in Hematological Parameters in Mice. Expert Opinion Environmental Biology 6(2).

8. Sheradah, M. A., Abd El Moneam, N. M., Yakout G., Abu-Ela HM. (2018a). Bacteria from Marine Sponges: A Source of Biologically Active Compounds. Biomedical Journal of Scientific \& Technical Research 10 (5), 1-20.

9. Shreadah MA, Abd El Moneam NM, Al Assar SA, Asmaa Nabil Adam A (2018) Phytochemical and pharmacological screening of Sargassium vulgare from Suez Canal, Egypt. Food Sci Biotechnol 27(4): 963-979.

10. AboulEla HM, Shreadah MA, Abdel Monem NM, YakoutGA, Van SoestRWM (2012) Isolation, cytotoxic activity and phylogenetic analysis of Bacillus sp. bacteria associated with the red sea sponge Amphimedonochracea. Advances in Bioscience and Biotechnology 3 (7): 815-823.

11. Elkomy RG, Ibraheem IB, Shreadah MA, Mohammed R (2015) Optimal Conditions for Antimicrobial Activity Production from Two Microalgae Chlorella marina and Nevicula F delicatula. Journal of Pure and Applied Microbiology 9(4): 2725-2732.

12. Elkomy RG, Ibraheem IB, Shreadah MA, Mohammed R, Ismael AA (2015) Antibacterial and Antifungal Activity of Three Microalgae Isolated from Egyptian Coast of the Mediterranean Sea. Journal of Pure and Applied Microbiology 9(4): 2751-2758.

13. Rizzo C, Lo Giudice A (2018) Review Marine Invertebrates: Underexplored Sources of Bacteria Producing Biologically Active Molecules. Diversity 10(52): 1-36.

14. Kumar MS, Pal AK (2016) A review of bioactive compounds from marine organisms with special mention on the potential of marine sponges in pharmacological applications. Journal of the Marine Biological Association of India 58(1): 83-91.

15. Nazim K, SK Sherwani, MU Khan, R Kausar, G Rizvi (2014) Antibacterial activity of marine sponge collected from Sunhari Beach. FUUAST J Biol 4(2): 233-236.

16. Shriadah MA, Okbah MA, El Deek MS (2004) Trace metals in the water columns of the Red Sea and the Gulf of Aqaba, Egypt. Water Air Soil Pollution 153(1): 115-124.

17. Okbah MA, Shata MA, Shriadah MA (2005) Gochemical forms of trace metals in mangrove sediments-Red Sea (Egypt). Chem Ecol 21: 23-36

18. Shreadah MA, Masoud MS, Said TO, El Zokm GM (2008) Application of IR, X-Ray, TGA and DTA to determine the mineral composition of the Sediments and study of reaction kinetics along the Egyptian Red Sea Coasts. Egypt J Aquat Res 34(2): 83-95.
19. Shreadah MA, Said TO, Abd El Ghani SA, Ahmed AM (2008) Alkyllead and Alkyltin species in different fishes collected from the Suez Gulf, Egypt. Proceedings of the $2^{\text {nd }}$ International conference on aquatic res. Egypt J Aquat Res 34(4): 64-73.

20. Shreadah MA, Said TO, El Zokm GM, Masoud MS (2008) Physicochemical characterititics of the surficial sediments along the Egyptian Red Sea coasts. Egypt J Aquat Res 34(4): 16-34.

21. Shreadah MA, Masoud MS, Said TO, El Zokm G (2008d) Application of IR, X-Ray, TGA and DTA to determine the mineral composition of the Sediments and study of reaction kinetics along the Egyptian Red Sea Coasts. Egyptian J Aqu Res 34(2): 83-95.

22. Gurguess SM, Shreadah MA, Fahmy MA, Aboul El Kheir E, Abdel Halim AM (2009) Assessment of water quality in the Red Sea using in situ measurements and remote sensing data. Egypt J Aquat Res 35(2): 1-13.

23. Masoud MS, Said TO, El Zokm G, Shreadah MA (2010) Speciation of Fe, $\mathrm{Mn}$ and $\mathrm{Zn}$ in Surficial Sediments from the Egyptian Red Sea Coasts. Chemical Speciation and Biodiversity 22(4): 257-269.

24. Masoud MS, Said TO, El Zokm G, Shreadah MA (2012) Assesment of Heavy Metals Contamination in Surface Sediments of the Egyptian Red Sea Coasts. Asturalian Journal of Basic and Applied Sciences 6(6): 44-58.

25. Mosmann T (1983) Rapid colorimetric assay for cellular growth and survival: application to proliferation and cytotoxicity assays. J Imm Meth 65(1-2): 55-63.

26. Said TO, Shreadah MA, Abdel Ghani SA, Ahmed AM (2010) Alkyltin and alkaylleadcompounds in coastal water of Suez Gulf, Egypt. Egyptian J Aqu Res 36(1): 33-42.

27. Hegazy MF, Mohamed TA, Elshamy AMI, Hassanien AA, Abdel Azimd NS, et al. (2015) A New Steroid from the Red Sea Soft Coral Lobophytum Lobophytum. Natural Products Research 30(3): 340-344.

28. Hegazy MF, Gamal Eldeen AM, Mohamed TA, Alhammady MA, Hassanien AA, et al. (2015) Cytotoxic Constituents from the Red Sea Soft Coral Nephthea Sp. Natural Products Research 30(11): 1266-1272.

29. Abdel Halim AM, Abdel Nabi MA, Abdel Fattah LM, Fahmy MA, Abo El Khair EM, et al. (2016) Environmental studies on the Aqaba Gulf coastal waters during 2011-2013. Journal of Environmental Protection 7(10): 1411-1437.

30. Abo El Khair EM, Abdel Fattah LM, Abdel Halim AM, Abdel Nabi MA, Fahmy MA, et al. (2016) Assessment of the hydrochemical characteristics for the coastal waters of the Suez Gulf during 2011-2013. Journal of Environmental Protection 7(11): 1497-1521.

31. Fahmy MA, Abdel Fattah LM, Abdel Halim AM, Abdel Nabi MA, Abo El Khair EM, et al. (2016) Evaluations of the Coastal Water Quality of the Egyptian Red Sea during 2011-2013. J Environ Prot 7: 1810-1834.

32. Shreadah MA, Said TO, Abdel Ghani SA, Ahmed AM (2011) Distribution of Different Organotin and Organolead Compounds in Sediment of Suez Gulf. Journal of Environmental Protection 2(5): 545-554.

33. Weiner RM, Segall AM, Colwell RR (1985) Characterization of a marine bacterium associated with Crassostrea virginica (the eastern oyster). Applied and Environmental Microbiology 49(1): 83-90.

34. Shirling EB, Gottlieb D (1966) Methods for characterization of Streptomyces species. International Journal of Systematic Bacteriology16: 313-340.

35. Webster NS, Hill RT (2001) The culturable microbial community of the Great Barrier Reef sponge Rhopaloeides odorabile is dominated by an alphaproteobacterium. Marine Biology 138(4): 843-851.

36. Lyman J, Fleming R (1940) Composition of seawater. Journal of Marine Research 3: 134-146.

37. Sambrook J, Fritsch EF, Maniatis T (2001) Molecular Cloning, A Laboratory Manual. Spring Harbor Laboratory Press. 
38. Acinas SG, Anton J, Rodriguez Valera F (1999) Diversity of free-living and attached bacteria in offshore western Mediterranean waters as depicted by analysis of genes encoding 16S rRNA. Applied and Environmental Microbiology 65(2): 514-522.

39. Weisburg WG, Barns SM, Pelletier DA, Lane DJ (1991) 16S ribosomal DNA amplification for phylogenetic study. Journal of Bacteriology 173(2): 697-703.

40. Thanomsub B, Poomeechockchai W, Limtrakul A, Arunrattiyakorn P, Petchleelaha W, et al. (2006) Withdrawn: Chemical structures and biological activities of rhamnolipids produced by Pseudomonas aeruginosa B189 isolated from milk factory waste. Bioresource Technology, 98(5): 1149-1153.

41. Hentschel UM, Schmid M, Wagner L, Fieseler C, Gernert, et al. (2001) Isolation and phylogentic analysis of bacteria with antimicrobial activities from the Me diterranean sponges Aplysina aerophoba and Aplysina cavernicola. FEMS Microbiol Ecol 35(3): 305-312.

42. Tamura K, Peterson D, Peterson N, Stecher G, Nei M, et al. (2011) MEGA5: Molecular Evolutionary Genetics Analysis using Maximum Likelihood, Evolutionary Distance, and Maximum Parsimony Methods. Molecular Biology and Evolution 28(10): 2731-2739.

43. Wiley RA, Rich DH (1993) Peptidomimetics derived from natural products. Med Res Rev 13(3): 327-384.

44. Taga MS, EE Miller, DE Pratt (1984) Chia seeds as a source of natural lipid antioxidants. J Am Oil Chem Soc 61(5): 928-931.

45. Zhishen J, Mengcheng T, Jianming W (1999) Research on antioxidant activity of flavonoids from natural materials. Food Chem 64: 555- 559.

46. Mosmann T (1983) Rapid colorimetric assay for cellular growth and survival: application to proliferation and cytotoxicity assays. J Imm Meth 65(1-2): 55-63.

47. Vijayan P, Raghu C, Ashok G, Dhanaraj SA, Suresh B (2004) Antiviral activity of medicinal plants of Nilgiris. Indian J Med Res 120(1): 24-29.

48. Blois MS (1958) Antioxidant determination by the use of stable free radicals. Nature 181: 1199-2000.

49. Amarowicz R, Pegg RB, Bautista DA (2000) Antibacterial activity of green tea polyphenols against Escherichia coli K12. Nahrung 44(1): 60-62.

50. Green LC, Wagner DA, Glogowski J, Skipper PL, Wishnok JK, et al. (1982) Analysis of nitrate, nitrite and $15 \mathrm{~N}$ in biological fluids. Anal Biochem 126(1): 131-138.

51. Shirwaikar A, Shirwaikar A, Kuppusamy R, Isaac SR (2006) In Vitro Antioxidant Studies on the Benzyl Tetra Isoquinoline Alkaloid Berberine. Biol Pharm Bull 29(9): 1906-1910.

52. Bibi F, Faheem M, Azhar EI, Yasir M, Alvi SA, et al. (2017) Bacteria From Marine Sponges: A Source of New Drugs. Current Drug Metabolism 18(1): 11-15

53. Maheshwari R, Shreedhara SC, Polu PR, Managuli RS, Xavier SK, et al (2017) Characterization of the Phenolic Compound, Gallic Acid from Sansevieria roxburghiana Schult and Schult. f. Rhizomes and Antioxidant and Cytotoxic Activities Evaluation. Pharmacogn Mag 13(3): S693-S699.

54. Altemimi A, Lakhssassi N, Baharlouei A, Watson DG, Lightfoot DA (2017) Phytochemicals: Extraction, Isolation, and Identification of Bioactive Compounds from Plant Extracts. Plants (Basel) 6(4): 42.

55. Govinden Soulange J, Marie D, Kauroo S, Beesoo R, Ramanjooloo A (2014) Antibacterial Properties of Marine Sponges from Mauritius Waters. Tropical Journal of Pharmaceutical Research 13 (2): 249-254.

56. Suja Pandian R, Jayalakshmi M (2018) Pharmacological activity of Psidium guajava leaves - A review. World Journal of Pharmaceutical Research 7(8): 201-211.

57. Jeyakodi S, Krishnakumar A, Chellappan DK (2018) Beta CaroteneTherapeutic Potential and Strategies to Enhance Its Bioavailability
Shankaranarayanan. Nutri Food Sci Int J 7(4): 1- 6.

58. Dhayalan A, Gracilla DE, Dela Peña RA, Malison MT, Pangilinan CR (2018) Phytochemical Constituents and Antimicrobial Activity of the Ethanol and Chloroform Crude Leaf Extracts of Spathiphyllum cannifolium (Dryand. ex Sims) Schott. J Pharm Bioallied Sci 10(1): 15-20.

59. Yu X, Lin H, Wang Y, Lv W, Zhang S, et al. (2018) D-limonene exhibits antitumor activity by inducing autophagy and apoptosis in lung cancer. Onco Targets Ther 11: 1833-1847.

60. Lu H, Xu C, Zhang X, Liang Y, Liu X (2016) Antibacterial effect of limonene on food-borne pathogens. Journal of Zhejiang University (Agriculture and Life Sciences) 42(3): 306-312.

61. Victor Antony Santiago J, Jayachitra J, Shenbagam M, Nalini N (2012) Dietary d-limonene alleviates insulin resistance and oxidative stressinduced liver injury in high-fat diet and L-NAME-treated rats. Eur J Nutr 51(1): 57-68.

62. De Sousa DP ((2015) Bioactive essential oils and cancer. Springer International publishing AG.

63. Peter KV (2012) Handbook of herbs and spices. Second edition, vol. 1. Woodhead Publishing Limited.

64. Fujita K, Fujita T, Kubo I (2007) Anethole, a potential antimicrobial synergist, converts a fungistatic dodecanol to a fungicidal agent. Phytother Res 21(1): 47-51.

65. Knio KM, Usta J, Dagher S, Zournajian H, Kreydiyyeh S (2008) Larvicidal activity of essential oils extracted from commonly used herbs in Lebanon against the seaside mosquito, Ochlerotatus caspius. Bioresour Technol 99(4): 763-768

66. Park IK, Choi KS, Kim DH, Choi IH, Kim LS, et al. (2006) Fumigant activity of plant essential oils and components from horseradish (Armoracia rusticana), anise (Pimpinella anisum) and garlic (Allium sativum) oils against Lycoriella ingenua (Diptera: Sciaridae). Pest Manag Sci 62(8): 723-728.

67. Carteau D, Bassani D, Pianet I (2008) The Ouzo effect: Following the spontaneous emulsification of trans-anethole in water by NMR. Comptes Rendus Chimie 11(4-5): 493-498.

68. Jiang Q (2018) Natural forms of vitamin E: metabolism, antioxidant and anti-inflammatory activities and the role in disease prevention and therapy. Free Radic Biol Med 72: 76-90.

69. Gautam V, Kohli SK, Arora S, Bhardwaj R, Kazi M, et al. (2018) Antioxidant and Antimutagenic Activities of Different Fractions from the Leaves of Rhododendron arboreum Sm. and TheirGC-MS Profiling. Molecules 23(9): 2239-2251.

70. Tyagi T, Mala Agarwal M (2017) Phytochemical screening and GCMS analysis of bioactive constituents in the ethanolic extract of Pistia stratiotes L. and Eichhornia crassipes (Mart.) solms. Journal of Pharmacognosy and Phytochemistry 6(1): 195-206.

71. Ko G, Cho S K (2017) Ethyl linoleate inhibits $\alpha$-MSH-induced melanogenesis through Akt/GSK3 $\beta / \beta$-catenin signal pathway. Korean J Physiol Pharmacol 22(1): 53-61.

72. Palakkal L, Hukuman NHZ, Mullappally J (2017) Antioxidant activities and chemical composition of various crude extracts of Lepidagathis keralensis. Journal of Applied Pharmaceutical Science 7(6): 182-189.

73. Balla OY, Ali MM, Garbi MI, Ahmed Saeed Kabbashi AS (2017) Chemical Composition and Antimicrobial Activity of Essential Oil of Mentha viridis. Biochemistry and Molecular Biology 2(5): 60-66.

74. Nurain IO, Bewaji CO, Johnson JS, Davenport RD, Zhang Y (2017) Potential of Three Ethnomedicinal Plants as Antisickling Agents. Mol Pharm 14(1): 172-182.

75. Wiirzler LAM, Silva Filho SE, Aguiar RP, Cavalcante HAO, Roberto Kenji Nakamura Cuman (2016) Evaluation of Anti-inflammatory Activity 
of Estragole by Modulation of Eicosanoids Production. International Journal of Pharma And Chemical Research 2(1): 7-13.

76. Kntapo FM, Salisu AG, Rukaiyat M Said RM (2018) X-Ray flourescence (XRF) elemental composition of Euphorbia hirta Linn (Asthma weed) as a medicinal plant. Asian J Med Biol Res 4(1): 49-54.

77. Garg M, Singh J (2012) Quantitative ASS estimation of heavy metals and trace elements in marketed ayurvedic churna preparations in India. IJPSR 3(5): 1331-1336.

78. Dembitsky VM (2002) Bromo-and iodo-containing alkaloids from marine microorganisms and sponges. Russ J Bioorg Chem 28(3): 170182.

79. Pauletti PM, Cintra LS, Braguine CG, Filho AA, Silva MLA, et al. (2010) Halogenated Indole Alkaloids from Marine Invertebrates. Mar Drugs 8(5): 1526-1549.

80. Zenkov NK, Menshchikova EB, Kandalintseva NV, Oleynik AS, Prosenko $\mathrm{AE}$, et al. (2007) Antioxidant and antiinflammatory activity of new water-soluble sulfur-containing phenolic compounds. Biochemistry (Mosc) 72(6): 644-651.

81. Bandara RV, Padumadasa C, Peiris DC (2018) Potent antibacterial, antioxidant and toxic activities of extracts from Passiflora suberosa L. leaves. Peer J 6: e4804.

82. Chen H, Lan X, Wu Y, Ou Y, Chen TC, et al. (2017) The antioxidant activity and nitric oxide production of extracts obtained from the leaves of Chenopodium quinoa Willd. Biomedicine (Taipei) 7(4): 24.

83. Ruiz Torres V, Encinar JA, Herranz López M, Pérez Sánchez A, Galiano V, et al. (2017) An Updated Review on Marine Anticancer Compounds: The Use of Virtual Screening for the Discovery of Small-Molecule Cancer Drugs. Molecules 22(7): 1037-1074.

84. Abdelnasser SM, Yahya SMM, Mohamed WF, Asker MMS, Abu Shady HA, et al. (2017) Antitumor Exopolysaccharides Derived from Novel Marine Bacillus: Isolation, Characterization Aspect and Biological Activity. Asian Pacific Journal of Cancer Prevention 18(7): 1847-1854.

85. Gagné D, French RL, Narayanan C, Simonović M, Agarwal PK, et al. (2015) Perturbation of the conformational dynamics of an active-site loop alters enzyme activity. Structure 23(12): 2256-2266.

86. Hou V, Grivennikov SI (2014) Microbiome, Inflammation and Cancer. Cancer J 20(3): 181-189.

87. Uhl KL, Schultz CR, Geerts D, Bachmann AS (2018) Harmine, a dualspecifcity tyrosine phosphorylation-regulated kinase (DYRK) inhibitor induces caspase-mediated apoptosis in neuroblastoma. Cancer Cell Int 18: $82-96$

88. Lakshmi S, Prakash P, Essa MM, Qoronfleh WM, Akbar M, et al. (2018) Marine derived bioactive compounds for treatment of Alzheimer's disease. Frontiers In Bioscience Elite 10(1): 537-548.
ISSN: 2574-1241

DOI: 10.26717/BJSTR.2018.12.002218

Mohamed A Shreadah. Biomed J Sci \& Tech Res

This work is licensed under Creative Commons Attribution 4.0 License

Submission Link: https://biomedres.us/submit-manuscript.php

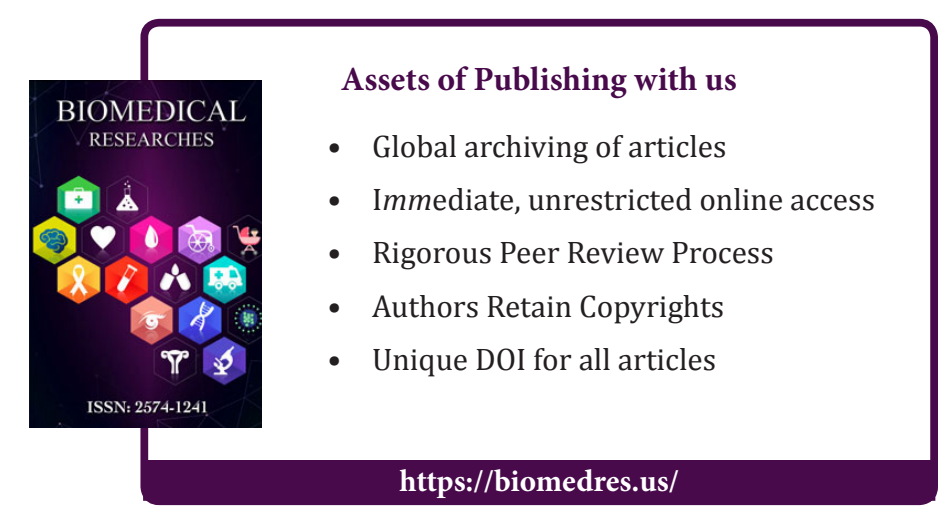

